\title{
Epidemiological characteristics of infectious hematopoietic necrosis virus (IHNV): a review
}

\author{
Peter Dixon ${ }^{1}$, Richard Paley ${ }^{1}$, Raul Alegria-Moran² and Birgit Oidtmann ${ }^{1 *}$
}

\begin{abstract}
Infectious hematopoietic necrosis virus (IHNV, Rhabdoviridae), is the causative agent of infectious hematopoietic necrosis $(\mathrm{IHN})$, a disease notifiable to the World Organisation for Animal Health, and various countries and trading areas (including the European Union). IHNV is an economically important pathogen causing clinical disease and mortalities in a wide variety of salmonid species, including the main salmonid species produced in aquaculture, Atlantic salmon (Salmo salar) and rainbow trout (Oncorhynchus mykiss). We reviewed the scientific literature on IHNV on a range of topics, including geographic distribution; host range; conditions required for infection and clinical disease; minimum infectious dose; subclinical infection; shedding of virus by infected fish; transmission via eggs; diagnostic tests; pathogen load and survival of IHNV in host tissues. This information is required for a range of purposes including import risk assessments; parameterisation of disease models; for surveillance planning; and evaluation of the chances of eradication of the pathogen to name just a few. The review focuses on issues that are of relevance for the European context, but many of the data summarised have relevance to IHN globally. Examples for application of the information is presented and data gaps highlighted.
\end{abstract}

\section{Table of contents}

1 Introduction

2 Aetiological agent, agent strains

3 Geographic distribution of the pathogen

4 Host range

5 Host infection

6 Environmental conditions suitable for infection and clinical disease

7 Exposed host population susceptibility parameters

7.1 Strain of salmonid fish and hybrids

7.2 Age and size of the fish

7.3 Rearing density

7.4 Stress

8 Minimum infectious dose

9 Virulence of IHNV strain

10 Subclinical infection
11 Time between pathogen introduction into an aquaculture site and detection

12 Prevalence

12.1 Prevalence in wild populations

12.2 Prevalence in farmed populations

12.2.1 Fish level prevalence

12.2.2 Farm level prevalence

12.3 Prevalence data from experimental studies

13 Shedding of the virus

14 Transmission via eggs

15 Diagnostic test performance

16 Pathogen load in fish tissues

17 Survival of IHNV in fish tissues

18 Vectors of IHNV

19 Conclusions

Additional file

\section{Introduction}

Infectious hematopoietic necrosis virus (IHNV) is an economically important pathogen causing clinical disease (Figure 1) and mortalities in a wide variety of salmonid
*Correspondence: Birgit.Oidtmann@cefas.co.uk

'Centre for Environment, Fisheries and Aquaculture Science, Weymouth, Dorset, UK

Full list of author information is available at the end of the article 


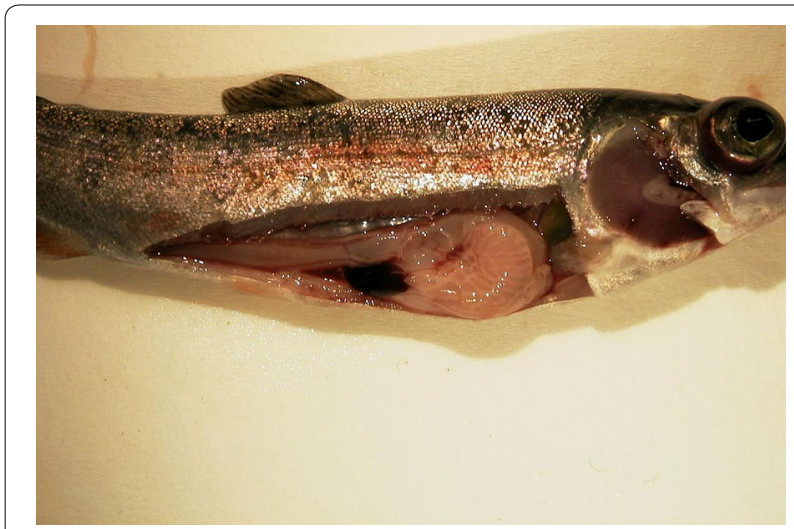

Figure 1 Gross pathology of infectious hematopoietic necrosis in rainbow trout. Typical gross appearance, including darkening of the skin, pale gills, exophthalmia, petechial haemorrhages, empty gut and ascitic fluid.

species, including the main salmonid species produced in aquaculture, Atlantic salmon (Salmo salar) and rainbow trout (Oncorhynchus mykiss). In 2013, the worldwide production of all farmed salmonids exceeded three million tonnes, with a value of $\$ 17.5$ billion [1]. Salmonid production, particularly Atlantic salmon, increased dramatically from 299000 tonnes in 1990 to 1.9 million tonnes in 2010, at an average annual rate near 10\% [2]. Infectious diseases are one of the main constraints to further expansion of aquaculture production [3]. Two epizootics of IHNV in Canada (from 1992 to 1996 and 2001 to 2003) caused a combined estimated economic loss to the salmon industry of $\mathrm{CDN} \$ 40$ million in inventory representing CDN\$200 million in lost sales [4]. Infection of fish with IHNV is notifiable to the World Organisation for Animal Health, and various countries and trading areas (like the European Union) have particular legislation in place for the control of the disease. Initially identified in western North America, the pathogen spread to Europe and Asia [5, 6]. Data on the characteristics of a given pathogen are relevant for several purposes. In the epidemiological context such data are required for the preparation of import risk assessments (e.g. to evaluate the risk of introducing a given pathogen to support animal health policy with regards to trade and biosecurity); the parameterisation of disease models (e.g. to predict disease spread in the case of an introduction of the pathogen); to evaluate the chances of eradication of the pathogen; for surveillance planning (e.g. following a disease outbreak or to demonstrate freedom from disease) to name just a few.

The review focuses on issues that are of relevance for the European context, but many of the data summarised have relevance to IHN globally.
The scope of the review covers characteristics of the pathogen, the hosts and the likelihood of detection, all of which provide information towards the likelihood of pathogen transfer and establishment.

It is often relevant to understand some details of the studies referred to in order to evaluate the information provided and use it for risk assessments. For this reason, we provided information on the context and/or methods of the referenced papers. This makes this review a relatively detailed document; however, this was done with the view to provide a reference document that allows scientists to refer to the summarised (but not too summarised) information without necessarily having to refer to all the original sources. An overview of the interaction between the various epidemiological factors covered in this review and their impact on disease control is presented in Figure 2.

\section{Aetiological agent, agent strains}

The causative agent of IHN, IHNV, is classified in the family Rhabdoviridae, and is one of three rhabdoviruses of finfish listed by the OIE (World Organisation for Animal Health). The IHNV virion is bullet shaped (Figure 3) and contains a single stranded, non-segmented, negative sense RNA genome of approximately 11000 bases which encodes six proteins in the order nucleoprotein $(\mathrm{N})$, phosphoprotein $(\mathrm{P})$, matrix protein $(\mathrm{M})$, glycoprotein $(\mathrm{G})$, non-virion protein $(\mathrm{NV})$ and polymerase $(\mathrm{L})$. The NV protein is unique and its presence has resulted in the establishment of a separate genus, Novirhabdovirus, within the Rhabdoviridae with IHNV as the type species and the Western Regional Aquaculture Centre (WRAC) isolate (Genbank Accession L40883 for sequence) as the type strain. There appears to be one serotype in comparisons using polyclonal antisera [7], although sub-types/ variants have been reported using monoclonal antibodies [8-10]. Different electropherotypes have been described (see Sect. 8), but the method currently most widely used for strain differentiation is through sequence analysis (e.g. [11]). Kurath et al. [11] designated three main virus genogroups [upper, middle and lower $(\mathrm{U}, \mathrm{M}, \mathrm{L})$ ] according, predominantly, to geographical range on the Western seaboard of North America. In general isolates from Pacific salmon form the $\mathrm{U}$ (sockeye salmon) and $\mathrm{L}$ (Chinook salmon) genogroups and display relatively limited genetic diversity indicative of historical evolutionary equilibrium whereas isolates from farmed rainbow trout in the USA form the M genogroup and show higher nucleotide diversity indicative of ongoing adaption to new host or conditions. The isolations from farmed rainbow trout in Europe and Asia (forming genogroups $E$ and J) appear to have originated in the USA and their introduction into new environments with novel host species 


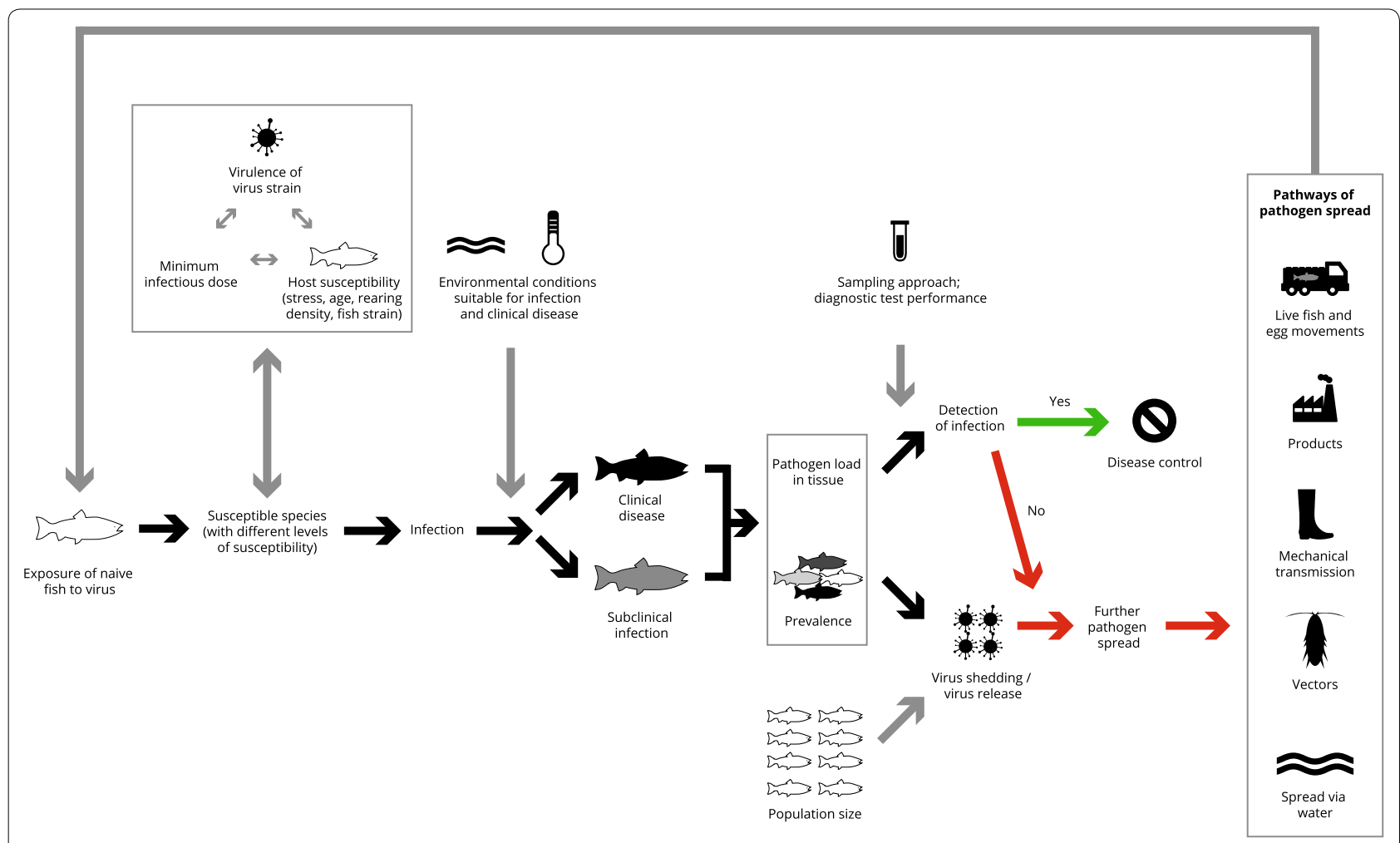

Figure 2 Interacting epidemiological factors covered in this review influencing establishment of IHNV infection and disease spread

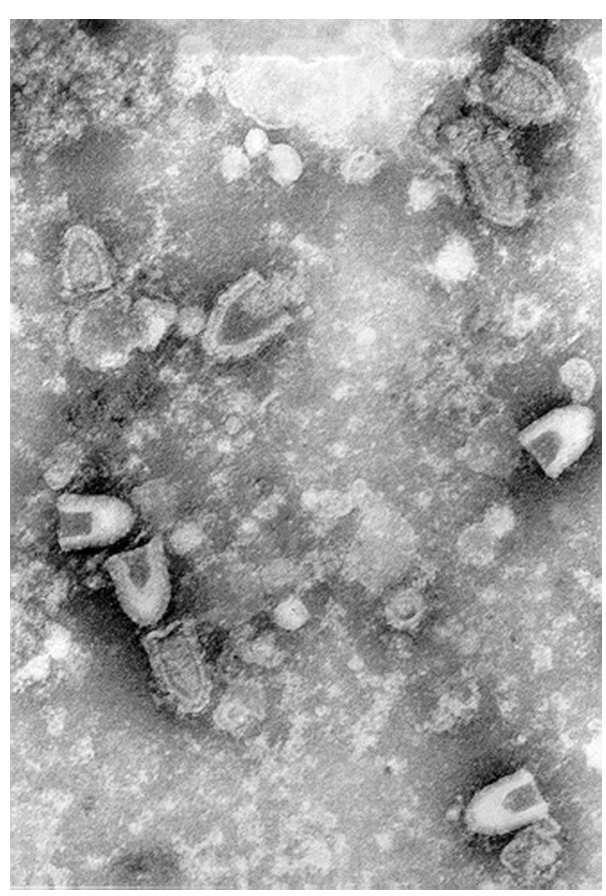

Figure 3 Transmission electron micrograph of infectious hematopoietic necrosis virus (IHNV). similarly leads to a high selection pressure on the pathogen, with very rapid evolution of IHNV $[12,13]$. There appears to be no correlation between serotypes and genotypes [14].

\section{Geographic distribution of the pathogen}

Initially identified in western North America, the pathogen spread to Europe and Asia. Historically, the virus has been reported from Austria, Belgium, Canada, Chile, China, Croatia, Czech Republic, France, Germany, Iran, Italy, Japan, Korea, The Netherlands, Poland, Russia, Slovenia, Spain, Switzerland, Taiwan and USA $[15,16]$.

According to the World Animal Health Information Database (WAHID-OIE, 2011 data) nine countries reported IHNV in domestic animals (fish produced in aquaculture) (Austria, China, Czech Republic, Germany, Italy, Japan, The Netherlands, Poland and Slovenia). Two countries reported cases in domestic and wild animals (France and USA) and one country reported the disease in wild animals only (Canada). The virus has recently been reported in the literature in wild fish in Kosovo [17] detected by RT-PCR only, and in cultivated fish in Turkey [18]. 
Table 1 Species susceptible to Infectious hematopoietic necrosis virus

\begin{tabular}{|c|c|c|c|c|}
\hline Scientific name & Common name & $\begin{array}{l}\text { Listed as } \\
\text { susceptible by EFSA [30] }\end{array}$ & $\begin{array}{l}\text { Listed as susceptible } \\
\text { by OIE diagnostic manual [16] }\end{array}$ & $\begin{array}{l}\text { Disease commonly } \\
\text { occurs/produces } \\
\text { significant mortality }\end{array}$ \\
\hline Oncorhynchus mykiss & $\begin{array}{l}\text { Rainbow trout, steelhead } \\
\text { trout }\end{array}$ & Yes & Yes & Yes \\
\hline Oncorhynchus tshawytscha & Chinook salmon & Yes & Yes & Yes \\
\hline Oncorhynchus kisutch & Coho salmon & Yes & Yes & Yes \\
\hline Oncorhynchus nerka & Sockeye salmon, kokanee & Yes & Yes & Yes \\
\hline Oncorhynchus keta & Chum salmon & Yes & Yes & Yes \\
\hline Oncorhynchus rhodurus & Amago salmon & Yes & Yes & Yes \\
\hline Oncorhynchus masou & Masu salmon & Yes & Yes & Yes \\
\hline Oncorhynchus clarki & Cutthroat trout & Yes & (Yes) & \\
\hline Salmo salar & Atlantic salmon & Yes & Yes & Yes \\
\hline Salmo trutta & Brown trout & Not assessed & (Yes) & \\
\hline Salmo marmoratus & Marble trout & Not assessed & Not listed & \\
\hline Salmo namaycush & Lake trout & Yes & (Yes) & \\
\hline $\begin{array}{l}\text { Salmo labrax (syn. } \\
\text { Salmo trutta labrax) }\end{array}$ & Black Sea salmon & Not assessed & Not listed & \\
\hline Salvelinus alpinus & Arctic char & Yes & (Yes) & \\
\hline Salvelinus fontinalis & Brook trout & Yes & (Yes) & \\
\hline Salvelinus leucomaenis & Char & Yes & (Yes) & \\
\hline Aulorhychus flavidus & Tube-snout & Yes & (Yes) & \\
\hline Thymallus thymallus $^{\mathrm{a}}$ & Grayling & Not assessed & Not listed & \\
\hline Esoxlucius & Northern pike & Yes & (Yes) & \\
\hline Plecoglossus altivelis & Ayu & Yes & (Yes) & \\
\hline Acipenser transmontanus & White sturgeon & Yes & (Yes) & \\
\hline Cymatogaster aggregata & Shiner perch & Yes & (Yes) & \\
\hline Clupea pallasi & Pacific herring & Yes & (Yes) & \\
\hline Gadus morhua ${ }^{a}$ & Atlantic cod & Yes & (Yes) & \\
\hline Sparus aurata & Gilthead seabream & $\|$ & No & \\
\hline Dicentrarchus labrax & European seabass & $\|$ & No & \\
\hline $\begin{array}{l}\text { Psetta Máxima/Scophthalmus } \\
\text { maximus }\end{array}$ & Turbot & $\|$ & No & \\
\hline Anguilla anguilla & European eel & $\|$ & (Yes) & \\
\hline
\end{tabular}

II: scientific data partially support susceptibility, (Yes): described in OIE manual as "have occasionally been found to be infected in the wild or shown to be somewhat susceptible by experimental infection".

a See comment in text.

\section{Host range}

Susceptible species are those from which the virus has been isolated or detected, but they do not necessarily exhibit IHN disease on a regular basis-if at all. Whether or not an aquatic animal species is susceptible to infection with a specific pathogen defines whether this species can potentially transmit the pathogen in question, either through trade of live animals or products (e.g. products for human consumption). Knowledge of the susceptible species range is therefore pivotal for containing disease spread and preventing its introduction into disease free areas. The listing of the susceptible species range is a core part of international trade regulations for aquatic animals (for trade into areas with a declared disease free status or undergoing programmes for disease eradication) [19, 20]. Knowledge of the susceptible species range is also relevant for targeting suitable species in surveillance programmes, e.g. to demonstrate freedom from infection or, in the event of an introduction of a given pathogen into a formerly disease free area, to establish its geographic spread. Species for which full or partial evidence for their susceptibility is available is summarised in Table 1.

In North America, IHN disease commonly occurs in sockeye salmon including the landlocked, kokanee form, Chinook salmon, rainbow trout (including steelheads) and Atlantic salmon [21]. Different strains of 
IHNV (identified in Sect. 2) are responsible for causing disease in these various species-this phylogenetic link between geographic isolation and species specific virulence is reviewed in Sect. 9. Where IHN occurs in Asia it is commonest in rainbow trout, chum and masu salmon [22-24]. In Russia the disease has only been recorded in sockeye salmon on the Pacific coast [25]. In Europe, IHN disease has only been recorded in rainbow trout [12]. The Atlantic salmon is a valuable cultured fish in certain European countries, but to date, IHNV has not been isolated from that species in Europe. Other species from which IHNV has been isolated in Europe, but usually without association with clinical disease, are the European eel [26, 27], Northern pike [28, 29], and brown trout [17]. Although not listed by either EFSA [30] or OIE [16], there is evidence suggesting that Black Sea salmon (Salmo labrax, syn. Salmo trutta labrax) [18], grayling (Thymallus thymallus) [31], and marble trout (Salmo marmoratus) [32] are also susceptible. Although Atlantic cod (Gadus morhua) is mentioned by both the EFSA report and the OIE diagnostic manual, the publication cited in the EFSA report [33] is based on an unnamed cod from the Pacific Northwest and hence is likely to be Pacific cod, Gadus macrocephalus, not Atlantic cod.

The identification of hosts not developing clinical disease are usually from single reports (and often as a side issue to the main subject of the report), which suggests that they are infrequent hosts and that significant mortality events in those species have not been observed.

These clear variations in the level of susceptibility of species to develop clinical disease have implications for planning of surveillance programmes, as clinical disease is usually associated with pathogen amplification [34]. For surveillance programmes, species most likely to develop clinical disease should be targeted, as this enhances the chance of pathogen detection. So for example in a fish farm that has both brown trout and rainbow trout, rainbow trout should be selected for sampling. However, when considering regulations, for example for control of live fish movements from infected farms, movements of species of low susceptibility (of low likelihood to develop clinical disease) would still need to be controlled as they pose a potential pathway of pathogen spread [35].

\section{Host infection}

Information on host infection is relevant to inform suitable diagnostic test and sampling of suitable tissues for testing, but also when considering routes of transmission. The main mode of infection of fish with IHNV is via water or food; the potential for vertical transmission i.e. within the egg is discussed in Sect. 14. The primary portal of entry of IHNV has been considered to be the gills, but tissues of the digestive system may become infected e.g. if fish, particularly fry, that have died from the disease are eaten by others.

The course of infection has been followed in experimentally infected fish by a range of techniques including virus isolation, histology and immunohistochemistry. The general picture that emerges for rainbow trout fry and fingerlings is that virus is initially detected in gill epithelium, skin, the oral region, pharynx, oesophagus, stomach and pyloric caeca at 1-2 days post infection followed by detection in kidney, spleen, thymus, liver, muscle and cartilage at 3-4 days post infection; by day 5 post infection virus can also be found in heart, pancreas and brain [36-39]. Infectious IHNV was also detected in blood or kidney leucocytes of bath infected rainbow trout at $6 \mathrm{~h}$ post infection in $9 \%$ of samples, rising to $70 \%$ of samples positive by $18 \mathrm{~h}$ post infection [40]. IHNV can replicate in leucocytes cultured in vitro [40], but the authors suggested that the importance of leucocytes in IHNV infections was in spreading the virus throughout the body of the fish. In the studies cited above, mortalities typically commenced around 5 days post infection with a virulent IHNV isolate.

Studies using recombinant IHNV expressing the luciferase gene [41] showed that in bath infected $0.5 \mathrm{~g}$ rainbow trout fry infected with $5 \times 10^{4}$ plaque forming units (pfu) virus $\mathrm{mL}^{-1}$, replication of virus was detected at the fin bases at $8 \mathrm{~h}$ post infection (although luciferase expression was first detected $2 \mathrm{~h}$ post infection at an unspecified location). No significant luciferase activity was seen in internal organs in the first 2 days but at 3 days post infection, the most active replication was in the spleen and kidney. In an initial experiment, luciferase activity on day 4 post infection was in the oral cavity, oesophagus, cardiac stomach, pyloric caecae, kidney and spleen as well as in the dorsal fin. The N gene and G gene of IHNV were detected at 1,4 and 6 days post infection in the dorsal fins of bath infected rainbow trout using a SYBR green real time RT-PCR [42].

All the above studies used rainbow trout as the target species, but there is no reason to suppose that the sequence of events following IHNV infection are substantially different in other host species.

The infection process can be very rapid. Immersion of juvenile Chinook salmon, mean weight $1.37 \mathrm{~g}$, in $5.7 \times 10^{3}$ pfu mL $\mathrm{mL}^{-1}$ IHNV for 1 min resulted in $30 \%$ infection with no mortality, but following a $10 \mathrm{~min}$ immersion in the same concentration of virus there was $70 \%$ infection and a low level of mortality $(<10 \%)$ [43]. Immersion of the Chinook salmon in $5.7 \times 10^{4} \mathrm{pfu} \mathrm{mL}^{-1}$ IHNV for $1 \mathrm{~min}$ also resulted in $70 \%$ infection and a low level of mortality. 
The results above suggest that following exposure of fish to high virus concentrations, virus detection could be possible within a few days post exposure. The virus can be found in a range of tissues and internal organs appear to become infected at a relatively early stage and are therefore suitable for sampling. Information regarding the viral load in various tissues is provided in Sect. 16. However, other factors, such as exposure dose (see Sect. 10), will influence progression to clinical disease and further spread of infection within a given host population. Subclinical infection may lead to low virus concentrations in tissues and escape detection using routine diagnostic methods.

\section{Environmental conditions suitable for infection and clinical disease}

Surveillance programmes, e.g. for demonstrating freedom from infection, should be designed in a way that maximises the likelihood of detection of the pathogen in question. The best conditions to detect infection is when clinical manifestation of infection is most likely. The clinical manifestation of IHNV infection is influenced by environmental conditions, including water temperature and salinity.

All outbreaks of IHN described to date from Europe and the majority of IHN outbreaks in North America occurred in freshwater. However, three major IHN epizootics have also been reported in Atlantic salmon held in sea net-pens in British Columbia, Canada [4, 44, 45]. The IHNV is endemic among populations of wild salmonids throughout much of the west coast of North America, but clinical disease is not usually reported in wild fish at the seawater stage $[16,46]$. Susceptibility of Atlantic salmon at the seawater stage with development of clinical disease and mortalities has also been shown experimentally by bath infection and/or cohabitation with experimentally infected fish $[4,47]$. The west coast of North America is outside of the natural range for Atlantic salmon.

Epizootics of acute IHN usually occur at water temperatures of $8-14{ }^{\circ} \mathrm{C}[16,21]$ and have not been reported above $15^{\circ} \mathrm{C}$ [48], although chronic outbreaks in Chinook salmon have been reported at temperatures above $17^{\circ} \mathrm{C}$ [43]. Under experimental conditions (freshwater) infection with mortality was induced in fingerling rainbow trout $(0.2-0.3 \mathrm{~g})$ at temperatures between 3 and $21{ }^{\circ} \mathrm{C}$ [49] following immersion in $10^{5} \mathrm{pfu} \mathrm{mL}^{-1} \mathrm{IHNV}$. When holding rainbow trout and sockeye salmon above $15.5^{\circ} \mathrm{C}$ before infection or moving fish to a minimum of $18{ }^{\circ} \mathrm{C}$ within $24 \mathrm{~h}$ after infection and maintaining them at that temperature for 4-6 days prevented or reduced mortality $[50,51]$.

Based on the available information, the best conditions to target susceptible freshwater fish species is when water temperatures are between $10-12{ }^{\circ} \mathrm{C}$. In the marine environment, although IHNV has been detected in a range of species, the only species in which clinical disease has been described-and is therefore most suitable to target in the marine environment for surveillance-is Atlantic salmon.

\section{Exposed host population susceptibility parameters}

Information about factors influencing host population susceptibility is relevant for estimating the likelihood of establishment of infection in exposed fish populations and for an understanding of which subpopulations within farms are most likely to develop infection and mortality or morbidity and should therefore be preferably be targeted in sampling programmes. This information can therefore be used to inform and design surveillance programmes, including risk-based surveillance. The information is also relevant to inform disease spread models, e.g. to simulate how quickly infection is likely to spread within a farmed or wild fish population.

Susceptibility to infection and disease depends on several factors, e.g. fish species (see Sect. 4), fish strain, life stage, and environmental conditions the animals are exposed to (including, stress and rearing density). Furthermore, fish susceptibility varies with viral strain (see Sect. 9). Since these factors can be present in multiple combinations and data are usually presented for one set of conditions, generalisations across species and conditions are difficult to make.

\subsection{Strain of salmonid fish and hybrids}

Besides variability in susceptibility between species (see Sect. 4), a range of studies have demonstrated variability of susceptibility to IHNV between strains or family lineages of fish. The average mortality of fry (progeny of 16 families of sockeye salmon generated by individual pair matings) challenged with IHNV ranged from 52 to $98 \%$; their susceptibility was suggested to be based on genetic differences [52]. In a similar study of rainbow trout from 22 different families (bath challenged with IHNV), mortality ranged from 65 to $100 \%$ in $1 \mathrm{~g}$ fish, from 33 to $90 \%$ in $8 \mathrm{~g}$ fish and $10-85 \%$ in $25 \mathrm{~g}$ fish [53]. Chinook salmon strains from Washington State were more susceptible at fry stage than strains from Alaska [54].

There have been a number of studies investigating resistance to IHNV in different clones or strains of rainbow trout. Gynogenesis was used to produce nine homozygous clones of rainbow trout from a domestic population of rainbow trout. The clones were bath challenged with IHNV and mortality ranged from 16 to $100 \%$ in fish of $<1.0 \mathrm{~g}$ [55]. A similar wide susceptibility range was observed in bath challenged rainbow trout from 25 
families having different growth rates [56]. Mortality ranged from 7.5 to $88.2 \%$. Survival was not correlated with growth rate per se, but body weight at challenge (using fish of a similar age from the different families) and survival were significantly correlated. Different strains of rainbow trout also differ in their antibody response to IHNV [57], which might also affect survival.

Use of hybrid fish strains has been shown to increase disease resistance. Triploid rainbow trout crossed with triploid coho salmon were significantly more resistant to experimental bath challenge with IHNV than pure crosses of either diploid or triploid rainbow trout [58]. This was confirmed in a later study which compared diploid and triploid pure crosses and hybrids of rainbow trout, brook trout and coho salmon for their resistance to IHNV. Progeny of female rainbow trout $x$ male brook trout and female rainbow trout $\times$ male coho salmon crosses were significantly less susceptible to bath challenge with IHNV than the pure rainbow trout cross [59]. Likewise, triploid rainbow trout $\times$ brown trout hybrids were more resistant to bath challenge with IHNV (3-7\% mortality) than pure rainbow trout (80\% mortality) [60]. However, crossing coho and Chinook salmon did not confer resistance to the virus [61].

There was significantly less mortality in the triploid brown trout female $x$ lake trout male hybrid progeny than in rainbow trout after bath infection with, or injection of IHNV [62]. The emergence of strains of IHNV from the MD subgroup of the M genogroup infecting steelhead trout was investigated in Washington State between 2007 and 2011. The overriding factor affecting emergence was variation in susceptibility of different populations of steelhead trout, rather than differences in the virulence of the virus strains, although the latter probably did have an effect. The resistance to some extent was heritable. The genetic basis for resistance in pure species and crosses has been investigated by a number of authors [63-73].

In summary, significant variability in mortality or morbidity levels is likely between fish strains. Increased resistance in certain fish strains means that detection of clinical disease (following infection), and therefore detection of infection is less likely. Increased levels of resistance are also likely to be associated with lower pathogen levels in fish tissues, making detection through routine sampling less likely. Where on a farm highly susceptible strains are present alongside more resistant strains, the highly susceptible strains should be selected for sampling.

Although such studies are currently not available, we would hypothesise that variations in susceptibility are also likely to impact on virus shedding, and prevalence (both likely to be decreased in more resistant strains), which will influence the dynamics of disease spread within a farmed fish population-which is relevant for disease modelling.

\subsection{Age and size of the fish}

Fish up to 2 months old appear to be the most susceptible to IHNV in natural and experimental infections, although adult fish may be infected without exhibiting clinical signs or mortality [48]. However, there have been occasional reports of mortality in older fish, such as 1 year old Atlantic salmon [44], 14-16 month old sockeye salmon smolts [74] and 2 year old kokanee [75]. Arkusch et al. [76] reported that sexually mature Chinook salmon experimentally infected with IHNV died within 14 days of infection.

The susceptibility of rainbow trout (Isle of Man strain) in relation to age and size $(2.5-3,15-20$ and $40-50 \mathrm{~g})$ was investigated by exposing the animals to six different IHNV isolates (five European and one North American) [27]. All isolates (varying in virulence) were detected in rainbow trout of all ages/weights for 28 days. The two most virulent isolates (both European) caused mortality in fish independent of their weight or age. Two other European isolates were virulent in fish up to a weight of $3 \mathrm{~g}$, but caused no mortality in larger fish [27].

LaPatra et al. [77] exposed four different age/weight groups of rainbow trout $(0.2-13.1 \mathrm{~g} ; 25-170$ days old) and kokanee (0.2-7.2 g; 45-210 days old) to four concentrations of two strains (electropherotypes, see Sect. 8) of IHNV by immersion to determine the relationship between host susceptibility and host age/size. Rainbow trout were susceptible to a type 2 strain of IHNV at all the age/sizes tested, but became less susceptible to the type 1 strain with increasing age/size. The $0.2 \mathrm{~g}$ (45 day) kokanee were equally susceptible to both virus strains based on $\mathrm{LD}_{50}$, but the other age/size fish were more susceptible to the type 1 strain. With increasing age/size, kokanee became refractory to the type 2 strain but appeared to have increased susceptibility to the type $1 \mathrm{IHNV}$.

Experiments to determine whether age and/or weight was the determinant in mortality of rainbow trout fry were reported by LaPatra [48]. Fry that hatched on the same date were fed according to three different regimes resulting in groups of fish that were the same age but of three different weights. There was no difference in the $\mathrm{LD}_{50}$ between the three groups following challenge with IHNV when they were 3 months old, but an increase in survival with an increase in weight at 4 months of fish age. When challenging fish of the similar weight (around $4.7 \mathrm{~g}$ ), but different age ( 3 or 4 months), the older fish were significantly less susceptible than the younger fish; however, when the experiment was repeated with fish of 4 and 5 months and similar weight, the older fish were more susceptible to the virus, which led the author to the 
conclusion that age or size alone does not determine host susceptibility. Recent work by Overturf et al. [56] indicated that weight of fish at challenge was an important determinant of survival in young rainbow trout of a similar age.

To summarise, for most host species, a decrease in susceptibly with increasing age or weight has been described.

For planning of surveillance programmes in freshwater farms, the reviewed data indicate that IHNV induced mortalities are most likely in juvenile fish (below $20 \mathrm{~g}$ ). As the highly susceptible life stages are also likely to carry high pathogen loads, juvenile fish should therefore be targeted for sampling. Although data are not fully comprehensive, there appears to be little or no correlation between fish size/weight and susceptibility in fish up to $20 \mathrm{~g}$.

It should be noted that (possibly due to costs) experiments usually use small fish. Apart from studies testing virus levels in fish around spawning time, data for near to market size fish are largely absent. Many of the studies use mortality as the measure of outcome. Subclinical infection therefore is often not captured.

\subsection{Rearing density}

Rearing density is likely to influence IHNV transmission within a population of susceptible fish, as naïve fish are at an increased chance of being exposed to relatively little diluted virus released by infected fish at increasing rearing density.

Rainbow trout $(1.2 \mathrm{~g})$ were cohabited with a single experimentally IHNV-infected donor rainbow trout for 11 days at rearing densities of $8,4,0.63,0.31,0.16,0.08$

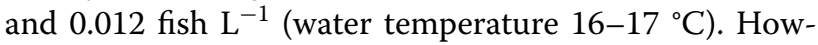
ever, at the end of the experiment, IHNV could only be isolated from 26 of 33 donor fish. No transmission was observed at the two lowest rearing densities, even though their donor fish were IHNV positive. At higher rearing densities, there was a direct relationship between rearing density and IHNV prevalence. At the highest rearing density, out of 60 exposed fish per setup (five repeats), between 1 and 4 became infected within the 11 day test period. The authors speculated that high rearing density could affect disease prevalence by (1) causing a deterioration in water quality leading to stress and a deleterious effect on the immune system and/or (2) increasing the likelihood of contact between naive fish and pathogen or infected fish [78].

The above mentioned study provides valuable information in that it demonstrates that increasing rearing density increases the probability of transmission and that at low densities transmission may not take place at all. The low rearing densities tested by the authors would not be expected to be found under farming conditions; they are more similar to what might be found in wild fish populations. At the highest rearing density tested (8 fish $\mathrm{L}^{-1}$, which would be a low to normal rearing density for this size of fish), transmission was consistently induced to naïve fish in all five replicate groups. At lower rearing densities, transmission from donor fish to naïve fish appeared to be a far more random event. As there are several factors influencing host population susceptibility, the transmission efficacy may vary depending on circumstances. The above mentioned experiments [78] provide a reproduction number, $\mathrm{R} 0$, relevant for the specific setup used in the study. R0 is one of the most crucial parameters needed for disease modelling. Although the study mentioned has clearly provided valuable information, further collection of data-either through field studies or experimental work-are important to explore how R0 may vary under different circumstances.

\subsection{Stress}

Stress caused by physical handling, acute environmental changes, and a range of other factors is known to decrease fish resistance to disease [48]. In adult sockeye salmon, prevalence of detectible IHNV infection and viral load in host tissues increased in IHNV endemic areas as the migration of fish upstream and the annual spawning event progressed $[46,79]$. Other stressors that have been noted in association with IHN disease epizootics include reduced food supply or high fish density of sockeye salmon in a lake in Alaska [80], low dissolved oxygen or high iron levels in groundwater from a well used in early incubation of eggs or fry of chum salmon [81], and high fish density allied with low water flow may have increased virus levels in, and subsequent shedding from spawning sockeye salmon [82]. Increased copper concentrations led to an increased susceptibility to IHNV compared with control animals [83], probably because of an immunosuppressive effect. In another study, rainbow trout were exposed to polychlorinated biphenyls (immunosuppressive in mammals), without significant effect on susceptibility to IHNV [84]. Exposure of 5-6 month old Chinook salmon to the insecticides chlorpyrifos and esfenvalerate did not increase the susceptibility of Chinook salmon to an isolate of IHNV isolated from steelhead trout and in some trials actually reduced the mortality in IHNV- and insecticide-treated groups $(4.7-11.4 \%$ cumulative mortality), compared with IHNV infected control groups (18.6-21.1\% cumulative mortality) $[85,86]$.

\section{Minimum infectious dose (MID)}

Information about MID is mainly relevant for risk assessments and disease modelling. In the context of risk assessments, the MID determines whether infection is 
likely to take place following exposure of a susceptible fish population to IHNV. This may be via a range of routes, such as introduction of virus via fomites or aquatic animal products (e.g. fish products imported for human consumption or contaminated eggs for aquaculture).

The MID combined with virus shedding rates could theoretically be used to model disease transmission, e.g. within a farmed fish population or with regards to downstream spread. In the farm level context, virus shedding rates in combination with MID might be used to estimate R0 (the reproductive number of disease transmission). Foreman et al. [87] used the combination of MID and shedding rate to model IHNV spread in Canada.

Despite IHN disease being known for over half a century, dedicated experiments to determine the MID are limited in the scientific literature. Early studies show infection with or without mortality at concentrations as low as $10^{2} \mathrm{pfu} \mathrm{mL}^{-1}[50,88,89]$. In kokanee $(0.2-7.2 \mathrm{~g})$ and rainbow trout $(0.2-13.1 \mathrm{~g})$ cumulative mortalities of up to 88 and $100 \%$ respectively were reported following bath exposure challenges at the lowest concentration tested of $10^{1.9} \mathrm{pfu} \mathrm{\textrm {mL } ^ { - 1 }}$ [77]. Conversely, mortalities in fingerling rainbow trout $(0.2-0.7 \mathrm{~g})$ bath challenged with virus concentrations increasing on a $\log _{10}$ scale between $10^{1}$ and $10^{5} \mathrm{pfu} \mathrm{mL}^{-1}$, were observed from $10^{3} \mathrm{pfu} \mathrm{mL}^{-1}$ or higher [83]. MID was shown to vary according to the isolate used and the host species tested, following challenge of Chinook salmon and rainbow trout with IHNV isolates of different electropherotypes, and of different host and geographic origin [90]. Studies cited above tended to use mortalities as the outcome measure for susceptibility. Further studies demonstrated that asymptomatic infections can occur in Chinook salmon when fish are exposed for as little as $1 \mathrm{~min}$ to $>10^{2} \mathrm{pfu} \mathrm{mL}^{-1}$. Progression to clinical disease was infrequent unless the challenge dose was $>10^{4} \mathrm{pfu} \mathrm{mL}^{-1}$ [43]. Atlantic salmon smolt (average weight $122 \mathrm{~g}$ ) reared in seawater of $10{ }^{\circ} \mathrm{C}$ were susceptible to infection at $10^{1}-10^{4} \mathrm{pfu} \mathrm{mL}^{-1}$ (exposed for $1 \mathrm{~h}$ ). Mortality was observed at all exposure concentrations, but only in one of duplicate tanks at the lowest dose. Variations in mortality rate were observed depending on exposure dose, and mean time to death was shorter in the higher challenge dose groups [4].

In summary, the MID appears to vary depending on fish species and for fry of the highly susceptible species to range between $10^{2}$ and $10^{3} \mathrm{pfu} \mathrm{mL} \mathrm{m}^{-1}$. In Atlantic salmon smolt, the MID was found to be even lower at $10^{1} \mathrm{pfu}$ $\mathrm{mL}^{-1}$. As stated before, host susceptibility is likely to vary depending on a range of factors such as rearing temperature, stress and several more. Therefore, the MID may not be automatically applied to a field situation. It also makes its use in the context of disease modelling more complex, as exposure of susceptible fish at the MID does not necessarily result in infection. In fact, near the MID, infection is a random event, which means transmission to a susceptible host population only takes place in a fraction of exposures at this dose.

The above also shows that the duration of virus exposure is crucial. In field situations, exposure concentration is likely to vary and may-depending on circumstancesonly last for short periods of time (e.g. wild infected salmon swimming close to an Atlantic salmon net cage; a batch of highly infected fish being processed and the liquid waste being discharged for a limited time period; first introduction of a contaminated fomite into an aquaculture facility).

\section{Virulence of IHNV strain}

Isolates of IHNV differ in the molecular weight of major structural proteins, which enabled the separation of strains into four types (termed electropherotypes) following electrophoresis [91]. That was later expanded into five types to accommodate isolates that had been incompletely characterised [92]. LaPatra [93] reported differences in virulence for rainbow trout of IHNV isolates from different electropherotypes. Following bath infection in rainbow trout, type 1 and 3 strains (potentially L genogroup, see below) caused 4 or $6 \%$ mortality, whereas a type 2 strain (potentially $M$ genogroup) caused $62 \%$ mortality. Further studies led to conflicting views as to the main factor affecting virulence: host $[47,77,94,95]$ or geographic origin of the virus [90].

Subsequently three genogroups of IHNV were described based on phylogenetic analysis of 303 field isolates from North America. The genogroups had three major geographic ranges in the Pacific Northwest, and were labelled Upper ( $\mathrm{U}$ ) for the northernmost group, Middle (M) and Lower (L) for the southernmost group [11]. These later studies support the hypothesis that geographic origin of the isolates played a greater role than host origin: Virulence of isolates of the three genogroups were compared by bath exposure of juvenile sockeye salmon, kokanee and two strains of rainbow trout. In sockeye salmon and kokanee the $U$ genogroup strains (three tested) were highly pathogenic $(69-100 \%$ mortality) whilst the $M$ strains (three tested) were hardly pathogenic (0-4\% mortality). However, the $\mathrm{M}$ genogroup strains were more virulent for rainbow trout $(25-85 \%$ mortality), whilst the $\mathrm{U}$ genogroup was less virulent (5-41\% mortality) for that species. The L genogroup (one strain tested) showed medium virulence to both sockeye and rainbow trout (13-53\% mortality) [96]. These data suggest that genogroup virulence is related to geographic origin of the virus strain. Virulence for a particular species may also be related to the long- or short term association of a strain with a particular host. For instance, it has 
been hypothesised that a $U$ genogroup strain (or strains) jumped from sockeye salmon to rainbow trout, evolving into the $\mathrm{M}$ genogroup and having greater virulence for the new host and losing virulence for the original one [11, 97]. The fitness of three pairs of IHNV M genotypes in the Columbia River basin was assessed by in vivo replication kinetics, host interferon-induced $\mathrm{Mx}-1$ expression during single infections and the ability to replicate in coinfection and superinfection studies in steelhead trout [98]. Increased fitness did not correlate with displacement of one genotype by another in the field, suggesting that other factors were important for such displacement events, such as increased ability to shed into the water, leading to increased chance of transmission or increased ability to persist in the host leading to increased duration and distance of transmission.

In summary, there are clear differences in virulence depending on viral strain and species infected. Although it is not absolute, in general a strain isolated from a given species corresponding to its historical phylogeographic host tends to be more virulent for the same species (i.e. virulence lower in other species).

Differences in virulence of strains are mainly relevant for predicting the outcome of IHNV exposure: where highly pathogenic IHNV strains are present in the relevant host species, the impact in terms of mortalities would be expected to be significant. On the other hand, infection with strains in a less relevant host may go unnoticed and movements of infected fish undertaken, until contact with a species more susceptible to the particular strain or conditions more suited for clinical expression leading to detection.

\section{Subclinical infection}

Subclinical infections play a particularly important role for the risk of spreading IHNV through live fish movements. Farmers may be unaware of infection in their stock and move fish to uninfected destinations. This is of particular concern if movements take place into disease free farms, zones or countries. Therefore, subclinical infections are of particular relevance for risk assessments, but also for disease spread modelling.

Subclinical infections tend to be associated with lower virus levels in affected fish compared to fish undergoing clinical infection [34], making detection through routine surveillance programmes difficult. As a result, this could lead to false assumption of freedom from infection.

Susceptibility to infection depends on a range of host factors, such as species and life stage (see Sect. 7) but also viral strain (Sect. 9) and environment (Section 6; Figure 2). The virus has been isolated from several fish species, but causes clinical disease associated with high mortalities only in a limited number of species, such as juvenile sockeye salmon, Chinook salmon, chum salmon, masu salmon, rainbow trout and Atlantic salmon [21-24, $44,99]$, Mortalities, usually at a low level have occurred in cultivated brown trout [100,101], but virus or evidence of virus has been detected in wild brown trout with no clinical disease in a number of countries [17, 102], leading to concerns as to the role of that species as a reservoir of the virus [17, 32]. Furthermore, subclinical IHNV infections have also been described in those species known to develop clinical signs, e.g. Chinook salmon [43], adult sockeye salmon $[46,79,103]$, rainbow trout, [104] and Atlantic salmon [105]. In the more susceptible species and life stages, subclinical infections tend to occur when fish are exposed to low doses of the virus and/or for short time periods, as has been shown in Chinook salmon fry [43]. Progression to clinical disease was infrequent unless the challenge dose was $>10^{4} \mathrm{pfu} \mathrm{mL}^{-1}$ [43].

Virus can be detected for months to over a year post exposure: in Chinook salmon IHNV was detected up to 39 days post exposure in subclinical fish after exposure to $1.9 \times 10^{3} \mathrm{pfu} \mathrm{mL} \mathrm{m}^{-1}$ (isolate fCLChn-n6 isolated from fall-run adult Chinook salmon from the Coleman National Fish Hatchery, i.e. potentially L genotype) [43]. Persistence of IHNV has been detected in rainbow trout survivors 1 year after exposure as fry, using immunohistochemical, molecular biology and electron microscopy techniques, though infectious virus was no longer detectable by plaque assay beyond 46 days post exposure [106]. Another study detected presence of persistent IHNV in rainbow trout survivors 18 months post infection, using RT-PCR in liver and kidney samples [104]. In Sockeye salmon fry (average weight $5.5 \mathrm{~g}$ ) bath infected with IHNV, which resulted in approximately $35 \%$ mortality over 4 months, virus was detected in the brains of survivors by reverse transcriptase real time PCR (RT-rPCR) 9 months post challenge [103].

Transmission of the virus has been demonstrated from asymptomatic post-smolt Chinook salmon to Atlantic salmon under experimental conditions [107]. Post-smolt Chinook salmon that had survived IHNV bath exposure passed infection on to Atlantic salmon as long as 5 months after the initial exposure, although transmission was more effective 22 days after the initial exposure [107]. At the end of the experiment (60 days after the Atlantic salmon were exposed to water from a tank containing asymptomatic, IHNV-infected Chinook salmon), none of the surviving Atlantic salmon were positive for IHNV but one of the surviving Chinook salmon was.

In areas where IHNV is endemic, the virus is generally rarely seen in adult fish except around the period of spawning [46, 79]. Clinical disease is uncommon in adult fish (see Sect. 7.2) and adult fish may carry the virus at 
undetectable levels until virus titres increase due to spawning stress. Infected wild fish populations rarely display clinical disease (e.g. [17]).

Further evidence for subclinical infection comes from experimental challenges, where susceptibility was demonstrated for a given fish species, but infection did not always concur with mortality or clinical signs [108]. Furthermore, IHNV was detected in non-clinical fish during surveillance programmes or surveys [34]. Therefore, species susceptible to infection but less likely to display clinical signs such as brown trout, brook trout and pike play a particular risk for unintended spread of the virus [35]. Similarly, life stages less prone to develop clinical signs (i.e. adult fish) may well be infected, but without detectable clinical signs [27]. Low virulent strains may lead to infection without causing clinical disease [27].

Overall, it is difficult to truly assess how common subclinical infection is, since due to limitations in diagnostic test sensitivity (see Sect. 15), subclinically infected fish may escape detection. Detection of antibodies against IHNV in fish may assist in the detection of carrier populations, as it indicates previous exposure. However, presence of IHNV antibodies is not necessarily indicting current infection with viable virus. Therefore, serological data would need to be carefully interpreted.

\section{Time between pathogen introduction into an aquaculture site and detection}

The time period between pathogen introduction onto a site and detection is relevant when dealing with an ongoing disease epidemic (e.g. when trying to contain spread, or establish geographical spread of infection), and also for disease modelling, as measures to prevent further spread may only be taken once infection on farm is suspected. The time to detection depends on several factors, including: amount of virus introduced into a new farm; incubation time period; speed of increase in prevalence; the existence of long time carrier status, and the capability of diagnostic tests to detect infection.

Most of the data on clinical infections with IHNV come from the experience in North America. There, typically, returning Pacific salmon are spawned, the progeny are raised in hatcheries and that is the time when clinical disease in fry is often observed. Migrating Pacific salmonids are not a feature of European aquaculture, and pathogen introduction onto a site does not follow the same pattern. In Germany, and probably many other European countries, the main mode of transfer of IHNV is by trade in infected fish [12, 35].

Infection on a farm site can remain undetected for long periods of time and may even remain undetected. With the exception of Atlantic salmon, virus concentrations required to induce infection and clinical disease in exposed salmonids appear to be relatively high $[4,109]$. On a farm site, this would mean that low level introductions would lead to a long delay before virus levels build up to levels leading to increased mortalities.

The much larger number of naive fish means that low level mortalities may not initially be picked up, until prevalence has reached relatively high levels. Adding to this is the difficulty of detecting dead or dying animals accurately. Exposure to low level concentrations (e.g. $10^{2} \mathrm{pfu} \mathrm{\textrm {mL } ^ { - 1 }}$ IHNV) often does not lead to detectable infection [43]; if it does, the virus may only be detectable for limited time periods [109]. Detection of the virus in fish long time periods after first exposure suggests that fish develop a carrier state, which escapes detection by routine diagnostic methods. Time periods between first exposure and re-emergence in individual fish can be as long as 1 year [106].

In outbreaks of IHN in Germany in 2006, time to appearance of noticeable change in mortality or appearance of clinical signs varied between a few weeks and 5-6 months. The long incubation periods occurred on farms that became infected in spring, when temperature had risen already to above $15{ }^{\circ} \mathrm{C}$ and infection only became clinically apparent when water temperature dropped again in autumn (E. Nardy, personal communication, March 2016).

\section{Prevalence}

Estimates of prevalence are relevant for planning surveillance programmes or for interpreting surveillance data. Surveillance programmes usually target farmed animals, as results have implications for the ability of farms to trade. Knowledge of infection levels in wild populations is of relevance where spill over of virus from wild to farmed fish (or vice versa) is suspected.

\subsection{Prevalence in wild populations}

In North America, IHNV is endemic among populations of wild salmonids throughout much of its historical range along the west coast of North America [16]. Studies in sockeye salmon have shown variability of detectable infection depending on life stage: juvenile sockeye salmon are fairly susceptible to infection [48]; between 1973 and 1999 the losses of juveniles as a percentage of eggs produced in Alaskan hatcheries ranged from 0 to $48.8 \%$ [110], although losses of up to $99 \%$ have been recorded [111]. In adult sockeye salmon, detectable prevalence is low or infection not detectable in fish returning from the sea to their spawning grounds (virus was found in 7 of 60 fish tested (12\%) at only one of four marine sites tested), but increases substantially when fish reach the spawning site [up to $50 \%$ (30 of 60 ) of fish tested were IHNV positive; results based on IHNV isolation] [46]. Data from 
long term studies showed an average prevalence in wild populations of female spawning Alaskan sockeye salmon (based on testing ovarian fluid) of $40.4 \%$ ( $\max 56 \%$, min 8.5\%; annual data from 1980 to 2000) and 53.6\% (min 11.3\%; max 60.3\%, annual data from 1980 to 1988) in postspawned females [110]. The proportion of fish with high viral titres $\left(\geq 10^{4}\right)$ was on average above $40 \%$.

In Europe, very few studies have investigated presence of IHNV in wild fish populations. In surveys undertaken in Switzerland in 1984, 1985 and 2000, IHNV was not detected in samples collected from wild fish populations (mainly brown trout). In total, tissue samples from near to 600 fish from natural habitats were tested by tissue culture. In addition, submissions of wild fish $(n=156$ between 1978 and 2000) to the lab from reported disease incidents did not detect IHNV. IHNV was not detected on fish farms in Switzerland in the years of the wild fish surveys (1984, 1985 and 2000), but between 1993 and 1999 [112].

A study of free-ranging rainbow trout in Germany in the vicinity of farms that had either confirmed outbreaks of IHN or had introductions of fish from known infected sources less than 4 months prior to sampling reported a prevalence of $35 \%$ (15 out of 43 rainbow trout testing positive) based on detection of IHNV neutralising antibodies [113]. It is not clear from the paper, whether the 43 fish were sampled from multiple locations. Detection of IHNV neutralising antibodies indicates exposure to the virus but not necessarily current infection. Therefore, the proportion of fish with IHNV neutralising antibodies are more likely an indication of the cumulative proportion of fish with prior exposure.

In a study from five rivers in the Republic of Kosovo, wild brown trout were sampled. Of a total of 32 pools (of five brown trout tissue samples, mixed fish sizes), eight pools tested positive for IHNV by RT-PCR (25.0\%). The positive pools were from 3 of the 5 rivers. No signs of disease had been detected in the sampled fish. Interestingly, IHNV was not detected in farmed rainbow trout from Kosovo during the study period (2006-2008). However, it was not reported whether the rainbow trout farms tested were located on the same rivers as the three from which brown trout tested positive [17].

As described above (Sect. 7.1), levels of susceptibility vary by species (e.g. rainbow trout are more prone to develop clinical disease compared to brown trout). Therefore, species with higher susceptibility would be more likely to test positive compared to less susceptible species. Furthermore, whereas IHNV is endemic in wild sockeye salmon populations on the west coast of North America, endemic infection in feral fish populations in Europe appear less common. This is likely to be a reflection of the susceptibility levels of feral fish species found in rivers.

\subsection{Prevalence in farmed populations 12.2.1 Fish level prevalence}

Statutory sampling programmes usually recommend or prescribe pooling of samples (see Sect. 15). In consequence most results available from farm surveys are from pooled samples, which does not allow determining fish level prevalence. One of the few studies reporting results at fish level tested rainbow trout from 30 farms in Germany, most of which had a history of IHN or viral haemorrhagic septicaemia (VHS) or a current VHS/IHN outbreak. IHNV was detected in 7 of the 30 farms by RTPCR, but only in three farms using virus isolation by cell culture. Of the fish tested from the seven IHNV positive farms, 59\% (23 of 39 fish) tested positive by nested RTPCR. At least one fish per farm tested positive by nested RT-PCR. PCR results were not broken down by number of fish positive against individual farms. Results of virus isolation are not reported by individual fish. The farms testing positive by RT-PCR but not by virus isolation had subclinical IHNV infection [34].

The dynamics of IHNV infection and disease were followed in a juvenile Chinook salmon population from North America both during hatchery rearing and for 2 weeks post-release. Cumulative weekly mortality increased from 0.03 to $3.5 \%$ as the prevalence of viral infection increased from 2 to $22 \%$ over the same fourweek period. The majority of the infected salmon were asymptomatic [43].

In adult Atlantic salmon from farmed populations that had experienced an outbreak of IHN a year before samples were collected, no live virus could be isolated, but more than $60 \%$ of the fish were positive for antibodies against the virus [105]. An IHN epidemic that occurred in Atlantic salmon over almost 2 years in British Columbia has been analysed [114]. Thirty-six farms were affected but a further 19 farms in the region were not. Over 12 million Atlantic salmon died or were culled during the epidemic, and losses on individual sites holding salmon for at least 14 weeks during the outbreak ranged from 20 to $94 \%$; higher mortalities occurred in populations that had been in seawater for $<1$ year (smolt populations) with reduced mortality in older populations.

No published data are available following prevalence of infection during the course of a clinical outbreak on farms in Europe.

As described above, host-factors (Sect. 7), environmental conditions (Sect. 6) and pathogen factors (Sect. 9) will influence the course of the disease (Figure 2), and in result detectable prevalence. These factors may vary between rearing units within a farm and therefore 
sampling programmes should target rearing units in which detection of the virus is most likely. Furthermore, prevalence obviously also depends on the stage within an outbreak. During the course of a clinical outbreak (depending on number of infected fish and/or infectious dose initially introduced into the farm) prevalence would be expected to increase from very low (well below 1\%) to considerably higher levels (possibly in excess of $50 \%$ ).

\subsubsection{Farm level prevalence}

The National Reference Laboratories for fish diseases in Europe provide reports on detection of IHNV on fish farms [115].

Out of 36 countries that provided data, seven considered one or more farms in their territory as IHNV infected in 2010. Amongst countries which reported IHNV on farms, the number of farms considered to be infected ranged from 1 (Belgium, Czech Republic) to 73 (Italy). Several countries had a considerable number of farms, for which the IHNV status was unknown. Therefore, farm level prevalence data cannot be derived.

Data for 2014 show a considerable change compared to 2010. Only one farm in Italy (out of 901 farms holding susceptible species) was considered to be infected with IHNV, and in Slovenia 28 (of 321) farms. Further countries reporting presence of the disease were Austria (1 farm), Belgium (1 of 90 farms), Croatia (4 of 304 farms), France (1 of 1622 farms), Germany (11 of 15812 farms), The Netherlands ( 8 of 59 farms), Poland ( 3 of 4442 farms) [116].

The picture that emerges for Europe is that-in contrast to the situation on the West coast of North AmericaIHNV is probably not endemic in wild fish populations. Detection of the virus in wild fish are most likely due to spill over of virus from farmed into wild fish populations, which-once the source of virus spill is removedappear to eliminate the virus over time. Introductions of the virus into previously virus free farms, are most likely from infected farms and not from the wild.

\subsection{Prevalence data from experimental studies}

Juvenile rainbow trout and sockeye salmon exposed to two different strains of IHNV (U and M strain) showed clearly different prevalences and mortalities depending on species and viral strain [117]. No mortalities were observed amongst the sockeye salmon, whereas mortalities were observed in most of the rainbow trout groups (72 h observation period). Prevalence was near to or $100 \%$ in both species when exposed to the $\mathrm{M}$ strain in a single infection. The U strain produced $100 \%$ prevalence in sockeye salmon (single infection), but only up to 18 out of 30 rainbow trout tested IHNV positive.
In an experimental study, prevalence (IHNV infection) in rainbow trout following exposure to IHNV infected rainbow trout ranged from 0 to $19 \%$ within 6 days post exposure (average fish weight ca. $1.2 \mathrm{~g}$ ) without clinical manifestation of the disease in the cohabitated fish within the 6 day observation period [109].

In conclusion: fish level prevalence depends on a number of factors including host species, life stage, IHNV strain, and stage within an epidemic (Figure 2). Very few data on fish level prevalence are available from farmed fish. Several susceptible species may carry IHNV in a clinical inapparent infection and in these circumstances, infection may not be detected by some diagnostic tests. Therefore for the planning of surveillance programmes and interpretation of surveillance data will need to take into account the factors affecting fish level prevalence. An overview of factors to consider in the design of a sampling programme is provided below (Sect. 19).

\section{Shedding of the virus}

Data on viral shedding rates per fish or biomass per time unit are essential to predict virus concentrations in the environment and as a result exposure levels for naïve fish cohabited with infected fish or exposed to virus contaminated water. Data on shedding rates per fish need to be combined with prevalence data to extrapolate shedding rates from a given fish population. These again will need to be put into context with water flow rates, which will dilute virus concentrations-possibly to levels below the minimal infectious dose.

Knowledge of virus excretion pathways and virus levels found in these fish excretions is relevant as they present the routes of pathogen release, which may have relevance for transmission pathways (e.g. egg associated transmission, see Sect. 14).

IHNV is shed in the external mucus and sexual fluids of fish [76, 110, 118-121]. It has occasionally been detected in faeces [122], but virus shedding via this route seems to be rare and of little relevance overall [121]. Some publications state that IHNV is shed in urine, but these authors have been unable to find any data in the scientific literature to substantiate that claim.

In juvenile fish undergoing an acute outbreak, the most relevant shedding route is therefore via mucus. In rainbow trout fry (mean weight $2.4 \mathrm{~g}$ ) the virus was detected in mucus from $24 \mathrm{~h}$ after water borne exposure and increased to levels near $10^{4}$ pfu mL $\mathrm{mL}^{-1}$ by $48 \mathrm{~h}$ post exposure, remaining at this level for at least 2 days. The virus was not detected $12 \mathrm{~h}$ following exposure, suggesting that virus was not contamination from the initial bath challenge. Virus concentrations were even higher $\left(10^{3.6}-10^{6.0} \mathrm{pfu} \mathrm{mL}^{-1}\right)$ in mucus of kokanee salmon and steelhead trout (mean weight $0.8 \mathrm{~g}$ ), which had died 
following IHNV exposure. Similarly high concentrations were found in Chinook salmon (mean weight $1.8 \mathrm{~g}$ ) that had died following natural infection. Virus levels were slightly lower in yearling Chinook salmon with chronic infection $\left(10^{1.3}-10^{2.4} \mathrm{pfu} \mathrm{mL}^{-1}\right)$ and adult steelhead trout (male and female) in spawning condition (mostly around $10^{2}-10^{3} \mathrm{pfu} \mathrm{mL}^{-1}$ ) [118]. Unfortunately, no data were provided on concentration of virus in rearing water in the days post challenge. Furthermore, rates at which the mucus is shed from fish per time unit and with it virus are not known. Therefore, shedding rates per time unit cannot be derived.

Several studies have reported virus concentrations in reproductive fluids. Virus levels range from 0 to $10^{10}$ pfu $\mathrm{mL}^{-1}[76,120]$ showing significant variation within populations (temporal trend) and between populations [120]. Virus levels tend to be higher in ovarian fluid compared to those in milt and prevalence tends to be higher in females compared to males [119-121]. Prevalence and virus levels were found to be higher in post spawning sockeye salmon ( 8 and 26 days post spawning) compared to spawning fish [110]. No data are available on rates of release of sexual fluids. Therefore, actual quantities of virus released via this route remain unclear.

A range of studies investigated IHNV levels in rearing water during IHN outbreaks in juvenile fish or from water holding adult fish around spawning time. Virus levels in water from holding channels of female sockeye salmon were up to peaks of $1600 \mathrm{pfu} \mathrm{mL}^{-1}$ for postspawning sockeye salmon, but were lower earlier on in the spawning period (in the order of $30-400 \mathrm{pfu} \mathrm{mL}^{-1}$ ) [82]. The extremely high titre of $1600 \mathrm{pfu} \mathrm{mL}^{-1}$ may have been caused by a disturbance of the sediment that took place prior to sampling leading to release of virus from the sediment, or by release of virus from decomposing spent salmon in the water [82].

Levels of $0.02-0.2 \mathrm{pfu} \mathrm{mL}^{-1}$ were detected in effluent from an adult steelhead holding pond, and 1 pfu per $3 \mathrm{~L}$ water from a river [123]. The amount of IHNV detected in river water in Japan was $0.5650 \%$ tissue culture infectious doses $\left(\mathrm{TCID}_{50}\right)$ per $\mathrm{L}$, and $5.60 \mathrm{TCID}_{50}$ per $\mathrm{L}$ was detected in pond water in which there was an outbreak of IHN in rainbow trout fry [124]. In another study, virus titres were recorded in water before and during an IHN epizootic in a steelhead trout rearing facility. Virus was not detected in the hatchery water supply or in adult fish holding ponds. In the early stages of an IHN outbreak when mortalities were low $(<20-250$ per day), median levels of virus in nursery tank water were $0.2-0.5 \mathrm{pfu}$ $\mathrm{mL}^{-1}$ increasing to $3 \mathrm{pfu} \mathrm{mL}^{-1}$ when daily mortalities were 500-2000. Levels of 5-50 pfu mL $\mathrm{m}^{-1}$ were recorded in rearing ponds that had received fry from the nursery tanks [125].
As rearing density and flow rates were not provided, shedding rates cannot be extrapolated from the above studies.

A study investigating release of virus from juvenile Chinook salmon showing clinical signs of IHN during an epizootic [43] reported immediate (after $1 \mathrm{~min}$ ) high levels (mean concentrations of near $1000 \mathrm{pfu} \mathrm{mL}^{-1}$; range: $50-2500 \mathrm{pfu} \mathrm{mL}^{-1}$ ) of virus following transfer of infected individual fish into eight separate static $100 \mathrm{~mL}$ containers at $13{ }^{\circ} \mathrm{C}$. Similar mean concentrations of $1000 \mathrm{pfu}$ $\mathrm{mL}^{-1}$ were also seen after 10 and $30 \mathrm{~min}$ (with a similar range to that at $1 \mathrm{~min}$ ). Fish mucus samples contained $6 \times 10^{4}-2 \times 10^{7} \mathrm{pfu} \mathrm{mL}^{-1}$ [43]. The immediate detection of high virus levels following placing of the fish in the container, which then remain relatively unchanged over the $30 \mathrm{~min}$ observation period, suggest that initial increase is due to initial mucus shedding-possibly due to transfer stress. This information is highly relevant, as it suggests that when fish are moved, there is an initial burst of virus release. Therefore, one should not necessarily assume a constant rate of virus shedding immediately after fish movements or stressful handling events that may be associated with mucus shedding. This is very significant, as it is this particular burst of virus shedding that could bring virus levels in a farm locally to levels where the MID is reached.

The first study to actually provide shedding rates over a longer time period was investigating the release of virus from IHNV infected Atlantic salmon. IHNV was detected before the onset of visible signs of disease with peak shed rates averaging $3.26 \times 10^{7}$ pfu fish ${ }^{-1} \mathrm{~h}^{-1}$ one to two days prior to mortality. Onset of shedding in individually reared fish was observed at the earliest on day 9 after bath exposure (not all of the bath challenged fish started to shed virus during the 3 week observation period), and at the earliest on day 5 in salmon injected with the virus. Shedding continued in some fish until the end of the 3 week observation period [4].

Using the data published by Garver et al. [4] shedding rates from marine Atlantic salmon farms during the peak rate of shedding for a farm of 500000 fish was estimated at $1.6 \times 10^{11}$ and $3.2 \times 10^{9} \mathrm{pfu} \mathrm{fish}^{-1} \mathrm{~h}^{-1}$ for a vaccinated population [87].

\section{Transmission via eggs}

Knowledge of likelihood of transmission of IHNV via eggs is relevant in the context of risk assessments for international trade, for risk pathways of pathogen introduction between farms to inform risk-based surveillance, for modelling of disease transmission, and for the assessment of potential sources of pathogen in an outbreak investigation. 
To review the literature on this topic, we assumed the following definitions: vertical transmission means the transfer of infection from parents to progeny through infection of the fertilized egg by the pathogen. The eggs become infected during development in the ovaries or when penetrated by contaminated or infected sperm. In contrast, egg surface-associated transmission means the transfer of infection from parents to progeny through contamination of the egg surface with the pathogen.

IHNV was shown to adhere to sperm under experimental conditions [126]. Some studies (e.g. [127]) report egg associated transmission of IHNV, however without providing sufficient detail or evidence to discriminate whether the transmission to progeny was via vertical or surface associated transmission. On the other hand, fry hatched from eggs of IHNV-positive female rainbow trout did not become infected, when eggs were incubated in IHNV-free water [121]. IHNV could not be detected in masu and chum salmon eggs injected with a dose of $10^{3.75} \mathrm{TCID}_{50}$ IHNV shortly after fertilization by 1 week (after injection masu salmon eggs), and by 5 weeks after infection (in chum salmon eggs), suggesting that IHNV is unlikely to survive within eggs [128]. The results of the latter study suggests that true vertical transmission is unlikely. However, there are also studies demonstrating IHNV infection in progeny of infected broodstock after disinfection of the egg surface: IHNV outbreaks were observed in first feeding fry in 2 out of 7 years in progeny derived from natural summer runs of steelhead trout from a river known to have IHNV-positive fish populations. Eggs were disinfected with an iodophor at water hardening (100 ppm for $1 \mathrm{~h}$ ) and at the eyed egg stage (100 ppm for $10 \mathrm{~min}$ ). Hatchery water source came from deep wells. The authors suggested that viral titres may have been so high in ovarian fluid that disinfection protocols were insufficient [129]. Further evidence that disinfection protocols of salmonid eggs are not always effective was provided by another study: Disinfection with $100 \mathrm{ppm}$ iodophor for $60 \mathrm{~min}$ at $10^{\circ} \mathrm{C}$ did not result in complete inactivation of $\mathrm{IHNV}$ on experimentally infected green and eyed rainbow trout eggs [130]. Eggs had been exposed to initial titres of $1.8-8.5 \times 10^{6} \mathrm{pfu}$ $\mathrm{mL}^{-1}$ IHNV (mimicking an exposure scenario of high viral titres in ovarian fluid) for $60 \mathrm{~min}$. Viable virus titres did decrease by more than $99.98 \%$, however, final titres were still in the order of $10-10^{4} \mathrm{pfu} \mathrm{mL}^{-1}$.

Although egg disinfection is not $100 \%$ reliable, it is very effective in reducing the likelihood of transmission by IHNV, and it is used routinely in many production facilities [51].

Quantitative estimates for the probability of transmission of IHNV via eggs were provided through an expert consultation. Experts estimated that under the assumption that the source site was sub-clinically infected, of 100 consignments of non-disinfected rainbow trout eggs, 30 would lead to infections of IHNV at receiving sites. If eggs were disinfected, the experts estimated that 5 out of 100 egg consignments would lead to infections of IHNV at receiving sites [35].

The information provided through studies cited above suggest that it is likely that any reports of IHN outbreaks in progeny are the result of inadequate disinfection of eggs that came from broodstock that were likely infected (but not tested) or known to be moderately or severely infected. It appears that disinfection protocols need to consider the health status of broodstock. Water inputs also need to be addressed as well as other potential sources of virus introduction such as equipment and people. More than one standardized protocol may need to be developed to address common practices of salmonid egg producers.

\section{Diagnostic test performance}

Timely diagnostic confirmation of the infectious status of individuals and populations is key to any ability to control disease outbreaks and the spread of infectious diseases. Methods recommended by the OIE for diagnosis of clinical IHN disease are isolation in cell culture followed by identification using a serological method [neutralisation, enzyme linked immunosorbent assay (ELISA), indirect fluorescence antibody test (IFAT)] or a molecular biology method (RT-PCR, DNA probe or sequencing). Alternatively, any two of the following tests: antibody-based assays, DNA probe or RT-PCR can be used. RT-PCR should always be followed by sequencing to confirm the identity of the amplicon [16]. The method recommended by OIE for surveillance for the virus is isolation in cell culture followed by identification using a serological or molecular biology method [16].

In Europe the recently released EU Commission Decision 2015/1554, including Annexe 1 on "Surveillance and control methods" and Annexe II on "Detailed diagnostic methods and procedures" includes in Part 1 of each of these Annexes (concerning VHS/IHN), the use of either RT-qPCR or virus isolation (with confirmation) as suitable methods with equal weight.

The following paragraph summarises recommended sampling and testing procedures in Chapter 2.3.4 on IHN of the OIE Manual of Diagnostic Tests for Aquatic Animals 2015 [16]. Samples for surveillance should be taken when water temperatures are below $14{ }^{\circ} \mathrm{C}$ or at their annual lowest if above this. Recommended organs for testing are anterior kidney, spleen and heart or brain. For surveillance ovarian fluid and milt should be examined at least once annually. Samples can be pooled up to a recommended maximum of 10 fish. The recommended cell 
lines for virus isolation are EPC or FHM. Where relevant, inocula should be pre-incubated with antisera capable of neutralising infectious pancreatic necrosis virus (IPNV). Cell cultures should be inoculated at 1:100 and 1:1000 dilutions and incubated at $15{ }^{\circ} \mathrm{C}$ for $7-10$ days with regular monitoring for cytopathic effect (CPE). In the absence of CPE sub cultures are made in the same cell line and incubated for a further 7-10 days. There are a number of primer sets published for the identification of IHNV, and recommended primers are published in the OIE manual.

In cases where there is suspicion of subclinical disease or sampling populations that may be recovering from disease there is strong evidence that brain is an important sample for detecting persistent infection [103, 131].

A number of studies have compared virus isolation (VI) with RT-PCR, for example [34, 42, 102, 132-136]. BarlicMaganja et al. [132] used the same viral dilutions for virus isolation and RNA extraction and molecular detection (dilutions from $10^{-1}$ to $10^{-7}$ ) and did not find molecular methods to be more sensitive compared to cell culture [132]. McClure et al. [136] compared test performance of VI and RT-PCR (nested assay using a different primer set compared to Bergmann et al. [133] and Miller et al. [34]) using Atlantic salmon samples collected in the field. The authors found the operating characteristics (sensitivity and specificity) of RT-PCR were very similar to those of VI and suggested it could be used for field testing fish for IHNV. Samples were tested before and after freezing and the authors reported that there were more positives by VI after freezing; storage of samples in RNAlater ${ }^{\circledR}$ reduced the number of positive samples determined by RT-PCR compared with testing fresh tissue or tissue frozen without RNAlater ${ }^{\circledR}$. Dhar et al. [42] investigated the use of a non-lethal sampling of pectoral fin tissue as a means of diagnosing IHNV. They used SYBR green real time RTPCR assays to detect the $\mathrm{N}$ gene or G gene of IHNV in comparison with a plaque assay for IHNV using fin samples from apparently healthy rainbow trout and rainbow trout showing clinical signs of IHN. The assay for the G gene was more sensitive than that for the $\mathrm{N}$ gene and detected IHNV in $33 \%$ of the apparently healthy fish and in $67 \%$ of the fish showing clinical signs of IHN. That compares with 17 and $92 \%$ positive for the two groups of fish by plaque assay. The authors suggested that the higher numbers of clinically infected fish by plaque assay may have been because there may have been more than one virus strain in the field samples and the inability of the primer sets used to detect all such strains [42]. Purcell et al. [136] developed a universal RT-real time PCR to detect IHNV from a wide selection of geographic regions. The test was reproducible in different laboratories, and trials with field samples compared VI with the RT-rPCR. IHNV was detected in $10 \%$ of kidney samples using virus isolation compared with 70\% in the RT-rPCR. No samples were VI positive but RT-rPCR negative.

In three other papers, detection by RT-PCR appeared to be superior to VI. Miller et al. [34] reported that RTPCR was the more sensitive method as VI failed to detect 4 out of 7 farms as infected with IHNV, whereas all farms were correctly diagnosed using RT-PCR. Bergmann et al. [133] applied the tests to experimentally infected rainbow trout and found that RT-PCR was significantly more sensitive compared to cell culture. The authors included several IHNV isolates in the study. Hostnik et al. [135] investigated the effect of storing tissue samples and observed that RT-PCR was less affected by storage of samples compared to VI. A slightly higher sensitivity of RT-PCR was also confirmed by Knusel et al. [102].

Sampling regimes, including the required number of fish to be tested, are different according to the purpose of the testing-for example for diagnosis to confirm suspicion of reported clinical cases, for surveillance to determine prevalence or for inspection programmes to determine freedom from infection. The numbers sampled need to reflect population size and epidemiological units and typically larger sample sizes are required for surveillance and inspection programmes. Pooling of samples is often used as an approach when animals are either too small to test individually (e.g. fry) or more often to reduce the cost of testing programs. The OIE manual [16] currently recommends a maximum of 10 samples can be pooled for analysis by virus isolation, whereas the EU diagnostic manuals recommend a maximum of 10 for virus isolation but only five for RT-PCR based tests. These recommendations are not well supported by published references and indeed there is little work in the literature to evidence the effect of sample pooling on detection of IHNV. It is therefore generally recommended that laboratories undertake their own experiments to determine the effects of pooling on test sensitivity with the specific diagnostic tests they use. Most published diagnostic tests have undergone some test validation in order to satisfy peer review at the least. This is generally at the analytical level of test sensitivity (ASe) using known analytes of differing known concentration and specificity (ASp) across a range of related and unrelated pathogens in the laboratory. Diagnostic validation, referring to the assessment of the performance of a test on the real life samples for which it was intended, involves the assessment of a tests ability to correctly determine known positives [(diagnostic sensitivity (DSe)] and known negatives [(diagnostic specificity (DSp)] and thus its predictive value. Diagnostic test performance is a key factor determining the usefulness of inspection and surveillance programmes utilising a particular assay but in the aquatic animal field such 
diagnostic validation is rarely fully completed to OIE guidelines [19], partly because of the difficulty of obtaining funding for such work and logistically obtaining the required reference samples. IHN is one of the diseases for which some of the diagnostic tests are reasonably well supported by both analytical and diagnostic validation, possibly because of the long history of significant disease outbreaks in important natural populations in North America and associated hatchery reared restocking before the general rise in aquaculture of the 1970s and 80s. Even so there are very few publications on test validation for IHNV. McClure et al. in 2008 [135] validated the performance of virus isolation and the then current (2006 revision) OIE recommended RT-PCR assay (based on the $\mathrm{N}$ gene). Analysing 50 fish each from farms with high, low and no prevalence of infected fish (a limited number of samples) the operating characteristics of both assays were similar but with each missing over $10 \%$ of positives (DSe of 74-89\%). Diagnostic specificity ranged from 92 to $100 \%$. The authors recommended a larger sampling size to better validate this assay. The current RT-PCR assay recommended by the OIE (2012 revision) and EU diagnostic manuals is based on the $\mathrm{G}$ gene [137] but the reviewers were not able to find published validation for this assay. Real time PCR is rapidly taking over from conventional PCR in many diagnostic laboratories due to its faster turnaround and comparable sensitivity to a nested conventional PCR but with lower risk of contamination. Purcell et al. [136] recently developed and validated a reverse transcriptase real time PCR assay capable of targeting the $\mathrm{N}$ gene and capable of detecting all known IHNV genogroups . Diagnostic validation was undertaken on sample sizes of 50 positive and negative laboratory challenged steelhead trout samples and 60 juveniles from a hatchery undergoing a disease outbreak. The assay was compared to virus isolation and a single round conventional PCR (targeting a different gene) and proposed to be superior at the level of DSe (100\% compared to $84 \%$ for virus isolation). All three methods had equal and full specificity (DSp of $100 \%)$. The real time PCR assay method is now included in the recently released EU diagnostic manual, but is yet to be included in OIE diagnostic manual.

\section{Pathogen load in fish tissues}

Information on pathogen load is of particular relevance for import risk assessments via imported aquatic animal products derived from susceptible species, e.g. for human consumption or used as angling bait. Furthermore, knowledge of pathogen load in tissues is relevant for assessing the potential of pathogen release from mortalities left in fish rearing units and the potential of spread via movements of mortalities (e.g. where mortalities are moved to other farms for storage). The information is also relevant to inform best sampling approaches for diagnostic testing purposes.

Very little information is available on viral load in tissues imported for human consumption (i.e. muscle tissue, head tissues). In most studies, tissues had been frozen or stored prior to analysis. Therefore, the initial viral load is unknown. There was no common method with regards to sample preparation prior to analysis, time of storage, or storage temperature such that the results from the various studies cannot easily be compared. Also, the source of samples varied from fish sampled during naturally occurring outbreaks, infected by bath challenge, or infected by intraperitoneal injection. A summary of the available data is presented in Additional file 1. Values reported from carrier fish are clearly limited by the sensitivity of tests available for the detection of IHNV in tissues. It is quite possible that lower virus titres are present, but the theoretical limit of detection of virus isolation protocols is $1 \times 10^{2}$ virus particles per $g$ tissue input and sampling and analytical procedures (e.g. pooling, sub-standard storage) often mean this is not obtained and therefore lower virus concentrations would escape detection.

The viral load in clinical IHN disease can be very high, regularly up to $10^{8}-10^{9} \mathrm{pfu}^{-1}$ tissue and occasionally $10^{10} \mathrm{pfu}^{-1}$. However, the average titres are in the order of $10^{4}-10^{6} \mathrm{pfu}^{-1}$. Although several studies have determined the viral load in gills and brain, only one study has evaluated IHNV levels in the skin and none have done so for muscle. Of note are studies reporting detection of IHNV in mucus, in one report at up to $4 \times 10^{8} \mathrm{pfu} \mathrm{g}^{-1}$. Although high titres of IHNV can be detected in fish during disease outbreaks, the same is not so in surviving fish, in which virus cannot usually be detected. The conclusion is that virus is not present in those fish, or is present in a form or at level that cannot be detected by current analysis methods.

In the text below, we focused on the literature available for rainbow trout, since rainbow trout is the species of greatest importance in Europe in freshwater aquaculture in relation to transfer of IHNV. There are relatively few data on pathogen load in rainbow trout following natural infections, particularly of commodity-size fish, and far more data from experimental infections. Some of the data are derived from fish undergoing clinical disease, whereas the levels of virus found in apparently healthy fish are of greatest relevance to this review.

In naturally infected rainbow trout the level of virus in internal organs ranged from $10^{1.7}$ to approximately $10^{8}$ pfu $\mathrm{g}^{-1}$ which was similar to that in other species and in experimental infections. High titres of virus $\left(10^{7} \mathrm{pfu}\right.$ $\mathrm{g}^{-1}$ ) can be detected in brain or gill tissues during clinical 
disease, but the average titres in the gill of virus carrier fish was $10^{2.5} \mathrm{pfu} \mathrm{g}^{-1}$ (Additional file 1).

There are no data for level of virus in brain of carrier fish except for spawning and pre-spawning sockeye salmon, in which levels in the brain varied between $10^{2}$ and $10^{3} \mathrm{pfu} \mathrm{g}^{-1}$, compared with $5.4 \times 10^{3}-3.8 \times 10^{6} \mathrm{pfu}$ $\mathrm{g}^{-1}$ in the gill and $4.7 \times 10^{6} \mathrm{pfu} \mathrm{g}^{-1}$ in the spleen. Similar results have been obtained in other studies of spawning sockeye salmon $[46,79,89,119,127]$. There has been only one study in which the titre of virus was determined in skin (fin) tissue [138]. Virus was detected in fin tissue from 4 of 24 apparently healthy rainbow trout sampled during a disease epizootic at levels between $1.0 \times 10^{2}$ and $4.0 \times 10^{4} \mathrm{pfu} \mathrm{g}^{-1}$ and in clinically diseased fish at levels between $1.0 \times 10^{3}$ and $2.14 \times 10^{6} \mathrm{pfu} \mathrm{g}^{-1}$ [42] Levels of virus in muscle tissue have not been recorded. IHNV has been detected $\left(10^{2.2}-10^{2.7} \mathrm{pfu} \mathrm{g}^{-1}\right)$ in mucus of adult carrier rainbow trout and Chinook salmon [118]. The amount of virus was almost double that in spawning kokanee [118], and in moribund commercial size Atlantic salmon was $10^{3.3} \mathrm{pfu} \mathrm{g}^{-1}$ (G S Traxler cited by Evelyn [139]). In experimentally infected rainbow trout fry the amount of virus detected in mucus was $1 \times 10^{4}-4 \times 10^{8}$ pfu g ${ }^{-1}[38]$.

LaPatra et al. [138] assessed the risk of transferring IHNV with commodity rainbow trout (225-500 g). The fish exhibited spinal curvature or spinal compression and were considered to have had high likelihood of previously being infected with IHNV. The fish were negative for IHNV by virus isolation and nested reverse transcription polymerase chain reaction, but, there was no direct evidence that these fish had initially been infected with IHNV. LaPatra et al. [138] also experimentally infected groups of 100 rainbow trout (mean weight $100 \mathrm{~g}$ ) with IHNV and sampled survivors at weekly or biweekly intervals starting 34 days post infection (10 days or more following the last mortality). The only occasion in which virus was detected in kidney or brain was in one fish sampled 34 days post infection. The authors concluded that IHNV was cleared from the previously exposed rainbow trout.

The information provided above and in Additional file 1 shows that clinically infected fish can carry very high titres in all tissues tested and that also subclinically infected fish can carry significant virus levels. Survivors may possibly fully clear infection (although see Sect. 10), although virus level could also possibly fall below detectable levels rather than be completely cleared from hosts.

\section{Survival of IHNV in fish tissues}

Data for pathogen load in aquatic animal tissues need to be interpreted in combination with information on the persistence of the virus in these tissues. We explained the relevance of knowledge on pathogen load in the previous section (e.g. for analysis in import risk assessments, and design of sampling for diagnostic tests). The information presented here complements the previous section.

The data for survival of IHNV in fish tissues were often obtained from studies to determine parameters relevant to diagnosis of the disease, and so many of the data were obtained for virus survival in internal organs, brain tissue or fry. Most of the data were obtained from experiments in which fish material was seeded with virus. The data from individual trials are summarised in Table 2. The survival of virus in muscle was only determined in one trial in which a homogenate of muscle and skin from fingerling rainbow trout (minus heads, tails and viscera) were seeded with $10^{5.7} \mathrm{TCID}_{50} \mathrm{~mL}^{-1} \mathrm{IHNV}$ [140]. At $4{ }^{\circ} \mathrm{C}$, the most likely holding/shipping temperature of fillets, $10^{2}$ $\mathrm{TCID}_{50} \mathrm{~mL}^{-1}$ virus survived storage for 7 days. At that temperature the virus survived for 3 weeks in an extract of whole fry but it survived longer in individual organs; up to 4 weeks in liver and 5 weeks in brain. In several studies in which a range of temperatures was compared, the survival of virus was inversely proportional to the temperature. Inactivation of the virus suspended in cell culture medium or tissue extracts at different temperatures was similar at a particular temperature in both matrices, except that at $28{ }^{\circ} \mathrm{C}$ there was greater inactivation of IHNV in the tissue homogenate [141]. The authors of the study suggested that this was because $28{ }^{\circ} \mathrm{C}$ was near the optimum for the enzymes acting on the virus that had been released during homogenisation.

The data summarised in Sects. 16 and 17 highlight that IHNV can be present in high concentrations in fish tissues and fish mucus and that cold storage extends the survival of the virus. Where fish in incubation of disease are harvested, these fish could carry significant virus levels. The risk of transmission to naïve fish populations then depends on overall virus quantities released, e.g. with liquid processing waste or when used as predator bait. Of particular concern is processing of potentially infected fish on fish farms.

Experts considered on-site processing an important risk for IHNV introduction. They estimated that out of 100 farm sites receiving rainbow trout carcases for processing from other farm sites (of unknown infection status), five would become infected over a 12-month period. When the processing site received live infected fish, the estimate increased to 77 . The risk of infection from the presence of a fish processing facility within $5 \mathrm{~km}$ upstream was rated similar to the presence of wild fish populations or stocked fisheries (susceptible species) within $5 \mathrm{~km}$ upstream, for which estimates was that over a 1 year period, out of 100 independent farm sites (located in independent water catchments/sea water 


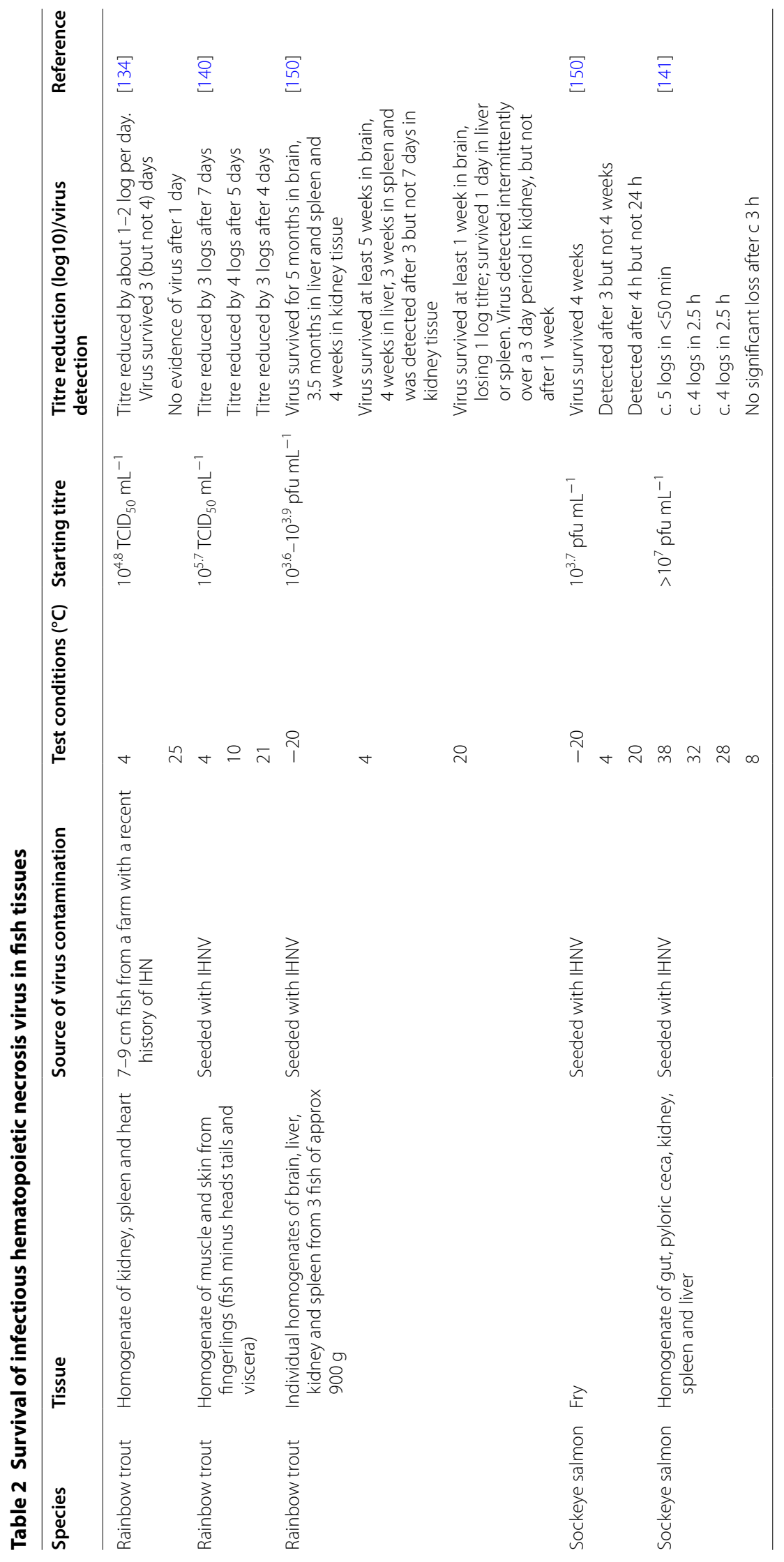


zones), 10 farm sites become infected. Receiving and storing fish waste (mortalities and processing waste) from other fish farms was considered to carry higher (1.5-fold) risk compared to mechanical transmission of IHNV through staff working on other fish farms (or staff from other fish farms working on the site) [35].

The relevance of potential introduction of aquatic animal viruses for potential pathogen spread was recognised by the World Organisation for Animal Health, OIE and led to a revision of all code chapters for aquatic animal pathogens $[19,142]$. As a result, eviscerated carcasses are no longer on the list of products that can be imported into disease free area without health certification.

\section{Vectors of IHNV}

A wide range of farmed fish from freshwater and the northern European marine environment, and to a much lesser degree farmed marine Mediterranean fish, are considered possible vectors of IHNV. Furthermore, there is evidence for the potential of IHNV transmission via invertebrates and piscivorous birds, and other animals may play a role.

A vector is typically defined as an organism that transmits a disease agent from one animal or plant to another. However, in a study to compile a list of vector species in aquaculture, the European Food Safety Authority (EFSA) narrowed and limited the definition of a vector species to (1) an animal that was farmed (2) that was traded live for farming purposes and (3) was non-susceptible to the disease in question [143]. That was in order to determine which vector species could be introduced for farming or restocking purposes into a specific disease-free zone of a member state of the European Union. [143]. Based on those criteria and under specific conditions (the vector species are sourced from the farm which keeps a susceptible species and are introduced to a new site with a susceptible species), members of the Acipenseridae, Cyprinidae, other freshwater fish (non-Cyprinidae), marine northern European fish and freshwater crustaceans were judged to have a moderate likelihood of being vectors of IHNV and marine Mediterranean fish a very low likelihood. If those specific conditions did not apply, the likelihood of those animals being vectors of IHNV was negligible [143] (see Sect. 10).

IHNV has been isolated from a number of invertebrates. IHNV was isolated from leeches (identity not given) collected from spawning sockeye salmon on three sampling periods at approximately 1 -week intervals. Leeches positive for IHNV increased from 67 to $100 \%$ over the 3 weeks, and on one occasion the virus titre was $>10^{6} \mathrm{pfu} \mathrm{g}^{-1}$ [89]. In another study IHNV was isolated from leeches (Piscicola salmositica) and a copepod (Salminicola sp.) both parasitizing sockeye salmon.
Average virus titres in pools of the copepods were $7.8 \times 10^{3} \mathrm{pfu} \mathrm{g}^{-1}$ and the range of titres in individual leeches was $2.5 \times 10^{1}-8.7 \times 10^{5} \mathrm{pfu} \mathrm{g}^{-1}$ [144]. There was no evidence that the virus replicated in the leeches. IHNV was isolated from adult Mayflies (Callibaetis sp.) collected from streams and an abandoned fish hatchery on a number of occasions, but the titre of virus was not determined [145].

Although isolation of IHNV from the invertebrates suggests that they may be vectors of the virus, evidence is sparse. One study [146] showed that the salmon louse, Lepeophtheirus salmonis, could transmit the virus in the laboratory. Although salmon lice are often considered not to transfer between hosts, such transfers have been observed under farmed and laboratory conditions, particularly when the host fish were kept at high densities $[146,147]$, and so this mode of transmission is feasible in aquaculture under certain circumstances. Lice exposed to $1 \times 10^{5} \mathrm{pfu} \mathrm{mL}^{-1} \mathrm{IHNV}$ in water and lice that parasitized Atlantic salmon experimentally infected with IHNV acquired the virus and those acquiring it from infected Atlantic salmon remained virus positive for $12 \mathrm{~h}$. In further experiments, lice that were exposed to IHNV in water or had parasitized experimentally infected Atlantic salmon were put in different tanks containing naive Atlantic salmon. Mortalities of 66.6 and $70.6 \%$ were observed in the two tanks of fish respectively, and IHNV was recovered from the majority of exposed fish. The authors concluded that under the experimental conditions the lice transmitted the virus to the fish, and transmission was likely to be mechanical rather than biological.

Experts estimated the number of farms (out of 100) becoming infected with IHNV over the course of 1 year due to short distance mechanical transmission (defined as introduction of pathogen from sources in close proximity to the farm through routes including: piscivorous birds or other animals and assuming no direct water connectivity). The experts estimated that one farm (or two farms) would become infected when assuming a country wide farm level prevalence of $2 \%$ (or $5 \%$ ) in a hypothetical country [35].

\section{Conclusions}

We have reviewed the peer reviewed literature to summarise the information relevant for a range of purposes, e.g. the preparation of import risk assessments; the parameterisation of pathogen spread models; for surveillance planning, including risk-based surveillance; to evaluate the chances of eradication of the pathogen.

To provide an example on using information presented in this review for surveillance planning:

If the purpose was surveillance to demonstrate freedom from IHNV in a defined geographic area (freshwater) in 
Europe, the sampling should (1) target species most likely to develop clinical infection if infected (e.g. rainbow trout); (2) target a life stage that is most likely to develop clinical disease if infected (i.e. fry, or adult fish post spawning); (3) the water temperature at which sampling should be undertaken is ideally $10-12{ }^{\circ} \mathrm{C}$; (4) if multiple rearing units fulfil the above criteria, animals that have been, or currently are subject to stressful conditions (e.g. recent grading, or poor water quality such as low oxygen levels) should be preferentially selected; (5) fish kept at high rearing density should be preferentially selected (since this may increase the chance of fish to fish transmission). Once rearing units meeting the above criteria have been identified, fish showing clinical signs of disease within these should preferentially selected. In contrast, sampling of non-stressed adult fish reared at low stocking density is most likely to return a negative test result, which does not mean though that the farm population is not infected.

Examples of factors to consider in models for IHNV spread via live fish movements are: species moved; size of the consignment; prevalence of infection in the consignment; rate of virus shedding by moved fish; host susceptibility parameters of fish at receiving farm (to estimate likelihood of infection establishing at receiving farm).

Significant variability in outcome of pathogen exposure was found for almost all factors that influence IHNV infection. For example, mortality levels may vary significantly depending on fish strain, virus exposure levels, water temperature-to name just a few. Modelling of pathogen transmission will therefore need to allow for fairly broad confidence levels. One aspect that is highly relevant for modelling the early phase of IHNV spread within a fish population, is that stressful events, such as netting of fish, or live fish movements, are likely to lead to mucus shedding. Mucus of infected fish may contain very high levels of IHNV. One study found an immediate (within $1 \mathrm{~min}$ ) rise of virus concentration in rearing water, after fish were transferred into a new container [43]. The consequence of such sudden bursts of virus release is that the minimum infectious dose could quite possibly be exceeded as a result.

The variability in outcome of pathogen exposure should also be considered in the design of surveillance programmes and the interpretation of test results from diagnostic samples.

The variability in outcome of virus exposure has implications for expected prevalences within susceptible fish populations and diagnostic test sensitivity (the likelihood of a diagnostic test to correctly identify an animal as infected, if infected). Knowledge of the diagnostic test sensitivity is relevant for surveillance planning, interpretation of data from disease investigations, evaluation of the chances of eradication, and also for the interpretation of many of the data presented in this review. With increasing size and age, some susceptible fish species (e.g. rainbow trout) appear less likely to be clinically affected and as a result the chance of detection of the virus is reduced. The consequence of failing to detect infection could be significant, since fish from such farms could be permitted to be moved live into declared disease free areas, despite carrying the virus.

Related to the above is the need for more information on subclinical infection, including for how long carrier status may persist. For example, to assess the likelihood of transmission of IHNV from subclinically infected to naive fish, information required (at a minimum) is: (1) knowledge about prevalence in subclinically infected populations; (2) the quantity of virus discharged from such fish per time unit; and (3) the minimal infectious dose for exposed species. Different challenge setups (e.g. longer exposure times in bath challenges) may be required to imitate realistic conditions in the field.

The majority of studies reviewed here were undertaken on the major salmonid species produced in aquaculture (Atlantic salmon and rainbow trout) and, with regards to wild fish, on sockeye salmon. Further information is urgently required on the risk of spread of IHNV via other commercially traded species (e.g. brown trout, Arctic char and grayling). Lack of data means that significant risks (e.g. risk of spread via live fish movements) may not be recognised and that international legislation possibly omits species that should be listed as susceptible, allowing trade of these species without conditions on IHNV health status. Live fish movements of fish species not listed as susceptible to IHNV under EU Directive 2006/88 played a role in IHNV epidemic in Germany in 2006, which led to a spread of the disease in 5 farms (Nardy, personal communication March 2016; [148]). Not listing species scientifically shown to be susceptible to IHNV in regulations controlling international trade for disease control purposes is significant as the industry may increasingly move to farming species not covered by the legislation, which could increase the risk of pathogen spread, as potentially infected fish would not be subject to requirements regarding their IHNV health status.

Reasons for lack of data in certain areas may possibly be due to limited interest within the scientific community or from funding organisations for such studies, as they don't always require advanced techniques to deliver results. However, the value of generating such data is significant.

One particular concern that arises from the review is that IHNV may affect the Atlantic salmon aquaculture industry beyond the Pacific coast of North America. The cause for emergence of IHNV in Atlantic salmon in 
North America was the introduction of a new species into an environment where IHNV was endemic in wild fish. As IHNV is not currently endemic in wild marine salmonid species outside of its natural range at the west coast of North America, the risk posed by IHNV is from a possible introduction of the pathogen via other pathways into farmed or wild fish populations with a possible establishment of IHNV in an endemic infection. The potential for wild Atlantic salmon populations to support IHNV in an endemic infection is currently unknown. The reviewed data suggest that IHNV could be a significant threat to the Atlantic salmon industry in Europe and other geographic areas in which Atlantic salmon are farmed.

\section{Additional file}

\section{Additional file 1. Infectious hematopoietic necrosis virus pathogen} load in fish tissues. Table with $\mathrm{HN}$ virus concentrations in a range of tissues from a variety of susceptible fish species.

\section{Competing interests}

The authors declare that they have no competing interests.

\section{Authors' contributions}

BO designed the structure of review and took the lead in drafting the manuscript. PD and RA-M drafted several of the individual sections of the manuscript. RP drafted the section on diagnostic methods and helped with the revision of the draft. All authors read and approved the final manuscript.

\section{Acknowledgements}

This work was funded through Defra projects FB002 and F1188, F1189, F1190, F1203 and F1211.

\section{Author details}

${ }^{1}$ Centre for Environment, Fisheries and Aquaculture Science, Weymouth, Dorset, UK. ${ }^{2}$ Faculty of Veterinary and Animal Sciences, University of Chile, Santiago de Chile, Chile.

Received: 23 November 2015 Accepted: 19 April 2016

Published online: 10 June 2016

\section{References}

1. Food and Agriculture Organisation (FAO) (2015) Global Production Statistics (online query). http://www.fao.org/fishery/statistics/en. Accessed 11 Oct 2015

2. Food and Agriculture Organisation (FAO) (2012) The state of world fisheries and aquaculture 2012. FAO, Rome, p 230

3. Jennings S, Stentiford GD, Leocadio AM, Jeffery KR, Metcalfe JD, Katsiadaki I, Auchterlonie NA, Mangi SC, Pinnegar JK, Ellis T, Peeler EJ, Luisetti T, Baker-Austin C, Brown M, Catchpole TL, Clyne FJ, Dye SR, Edmonds NJ, Hyder K, Lee J, Lees DN, Morgan OC, O'Brien CM, Oidtmann B, Posen PE, Ribeiro Santos A, Taylor NGH, Turner AD, Townhill BL, Verner-Jeffreys DW (2016) Aquatic food security: insights into challenges and solutions from an analysis of interactions between fisheries, aquaculture, food safety, human health, fish and human welfare, economy and environment. Fish Fish, in press

4. Garver KA, Mahony AAM, Stucchi D, Richard J, Woensel CV, Foreman M (2013) Estimation of parameters influencing waterborne transmission of infectious hematopoietic necrosis virus (IHNV) in Atlantic salmon (Salmo salar). PLoS One 8:e82296
5. Sano T (1976) Viral diseases of cultured fishes in Japan. Fish Pathol 10:221-226

6. Baudin Laurencin F (1987) IHN in France. Bull Eur Assoc Fish Pathol 7:104

7. Engelking HM, Harry JB, Leong JC (1991) Comparison of representative strains of infectious hematopoietic necrosis virus by serological neutralization and cross-protection assays. Appl Environ Microbiol 57:1372-1378

8. Winton JR, Arakawa CK, Lannan CN, Fryer JL (1988) Neutralizing monoclonal antibodies recognize antigenic variants among isolates of infectious hematopoietic necrosis virus. Dis Aquat Organ 4:199-204

9. Ristow SS, Arnzen de Avila J (1991) Monoclonal antibodies to the glycoprotein and nucleoprotein of infectious hematopoietic necrosis virus (IHNV) reveal differences among isolates of the virus by fluorescence, neutralization and electrophoresis. Dis Aquat Organ 11:105-115

10. Huang C, Chien M-S, Landolt M, Winton J (1994) Characterization of the infectious hematopoietic necrosis virus glycoprotein using neutralizing monoclonal antibodies. Dis Aquat Organ 18:29-35

11. Kurath G, Garver KA, Troyer RM, Emmenegger EJ, Einer-Jensen K, Anderson ED (2003) Phylogeography of infectious haematopoietic necrosis virus in North America. J Gen Virol 84:803-814

12. Enzmann P-J, Castric J, Bovo G, Thiery R, Fichtner D, Schuetze H, Wahli $T$ (2010) Evolution of infectious hematopoietic necrosis virus (IHNV), a fish rhabdovirus, in Europe over 20 years: implications for control. Dis Aquat Organ 89:9-15

13. Nishizawa T, Kinoshita S, Kim WS, Higashi S, Yoshimizu M (2006) Nucleotide diversity of Japanese isolates of infectious hematopoietic necrosis virus (IHNV) based on the glycoprotein gene. Dis Aquat Organ 71:267-272

14. Johansson T, Einer-Jensen K, Batts W, Ahrens P, Bjorkblom C, Kurath G, Bjorklund H, Lorenzen N (2009) Genetic and serological typing of European infectious haematopoietic necrosis virus (IHNV) isolates. Dis Aquat Organ 86:213-221

15. Hill B, Reese A, Dixon P, Oidtmann B, Paley R, Peeler E, Stentiford G, Stone D, Way K, Hine M, Calistri P, Ippoliti C, Di Lorenzo A, Savini L, Haenen O, Engelsma M (2010) Epidemiology of different agents causing disease in aquatic animals: Scientific review and database development. Scientific/technical report submitted to EFSA Question No EFSAQ-2008-05009 (CFP/EFSA/AHAW/2008/01) p147

16. World Organisation for Animal Health OIE (2015) Chapter 2.3.4.-Infectious haematopoietic necrosis, in manual of diagnostic tests for aquatic animals. OIE, Paris http://www.oie.int/en/international-standard-setting/aquatic-manual/access-online/. Accessed 6 October 2015

17. Rexhepi A, Berxholi K, Scheinert P, Hamidi A, Sherifi K (2011) Study of viral diseases in some freshwater fish in the Republic of Kosovo. Veterinarski Arhiv 81:405-413

18. Nishizawa T, Savas H, Isidan H, Ustundag C, Iwamoto H, Yoshimizu M (2006) Genotyping and pathogenicity of viral hemorrhagic septicemia virus from free-living turbot (Psetta maxima) in a Turkish coastal area of the Black Sea. Appl Environ Microbiol 72:2373-2378

19. World Organisation for Animal Health OIE (2015) Aquatic animal health code 2015. OIE, Paris http://www.oie.int/international-standard-setting/ aquatic-code/access-online/. Accessed 9 February 2016

20. Anonymous (2006) Council Directive 2006/88/EC of 24 October 2006 on animal health requirements for aquaculture animals and products thereof, and on the prevention and control of certain diseases in aquatic animals In: Union CotE (ed)

21. Bootland LM, Leong J-AC (1999) Infectious haematopoietic necrosis virus. In Woo PTK, Bruno DW (eds) Fish diseases and disorders, Vol 3: Viral, bacterial and fungal infections

22. Yoshimizu M, Kimura T (1992) Viral infections of cultured fishes in Japan. NOAA TechRep NMFS 111:43-47

23. Park MA, Sohn SG, Lee SD, Chun SK, Park JW, Fryer JL, Hah YC (1993) Infectious haematopoietic necrosis virus from salmonids cultured in Korea. J Fish Dis 16:471-478

24. Jeon CH, Kim SR, Kim WS, Lee CH, Seong KB, Lee CS, Oh MJ, Kim JH (2011) Monitoring of viruses in chum salmon (Oncorhynchus keta) migrating to Korea. Arch Virol 156:1025-1030

25. Rudakova SL, Kurath G, Bochkova EV (2007) Occurrence and genetic typing of infectious hematopoietic necrosis virus in Kamchatka, Russia. Dis Aquat Organ 75:1-11 
26. Joergensen PEV, Castric J, Hill B, Ljungberg O, De Kinkelin P (1994) The occurrence of virus infections in elvers and eels (Anguilla anguilla) in Europe with particular reference to VHSV and IHNV. Aquaculture 123:11-19

27. Bergmann SM, Fichtner D, Skall HF, Schlotfeldt HJ, Olesen NJ (2003) Age- and weight-dependent susceptibility of rainbow trout Oncorhynchus mykiss to isolates of infectious haematopoietic necrosis virus (IHNV) of varying virulence. Dis Aquat Organ 55:205-210

28. Dorson M, de Kinkelin P, Torchy C, Monge D (1987) Susceptibility of pike (Esox lucius) to different salmonid viruses (IPN, VHS, IHN) and to the perch rhabdovirus. Bull Fr Peche Piscic 307:91-101

29. Reschova S, Pokorova D, Hulova J, Kulich P, Vesely T (2008) Surveillance of viral fish diseases in the Czech Republic over the period January 1999-December 2006. Vet Med Czech 53:86-92

30. EFSA (2008) Scientific Opinion of the Panel on AHAW on a request from the European Commission on aquatic animal species susceptible to diseases listed in the Council Directive 2006/88/EC. EFSA J 808:1-144

31. Kolodziejek J, Schachner O, Duerrwald R, Latif M, Nowotny N (2008) "Mid-G" region sequences of the glycoprotein gene of Austrian infectious hematopoietic necrosis virus isolates form two lineages within European isolates and are distinct from American and Asian lineages. J Clin Microbiol 46:22-30

32. Pascoli F, Bilò F, Nonnis Marzano F, Borghesan F, Mancin M, Manfrin A, Toffan A (2015) Susceptibility of genotyped marble trout Salmo marmoratus (Cuvier, 1829) strains to experimental challenge with European viral hemorrhagic septicemia virus (VHSV) and infectious hematopoietic necrosis virus (IHNV). Aquaculture 435:152-156

33. Enzmann PJ, Kurath G, Fichtner D, Bergmann SM (2005) Infectious hematopoietic necrosis virus: monophyletic origin of European isolates from North American Genogroup M. Dis Aquat Organ 66:187-195

34. Miller TA, Rapp J, Wastlhuber U, Hoffmann RW, Enzmann PJ (1998) Rapid and sensitive reverse transcriptase-polymerase chain reaction based detection and differential diagnosis of fish pathogenic rhabdoviruses in organ samples and cultured cells. Dis Aquat Organ 34:13-20

35. Oidtmann BC, Peeler EJ, Thrush MA, Cameron AR, Reese RA, Pearce FM, Dunn P, Lyngstad TM, Tavornpanich S, Brun E, Stärk KDC (2014) Expert consultation on risk factors for introduction of infectious pathogens into fish farms. Prev Vet Med 115:238-254

36. Yamamoto T, Clermont TJ (1990) Multiplication of infectious hematopoietic necrosis virus in rainbow trout following immersion infection: organ assay and electron microscopy. J Aquat Anim Health 2:261-270

37. Yamamoto T, Batts WN, Arakawa CK, Winton JR (1990) Multiplication of infectious hematopoietic necrosis virus in rainbow trout following immersion infection whole-body assay and immunohistochemistry. J Aquat Anim Health 2:271-280

38. Drolet BS, Rohovec JS, Leong JC (1994) The route of entry and progression of infectious haematopoietic necrosis virus in Oncorhynchus mykiss (Walbaum): a sequential immunohistochemical study. J Fish Dis 17:337-347

39. Brudeseth BE, Castric J, Evensen O (2002) Studies on pathogenesis following single and double infection with viral hemorrhagic septicemia virus and infectious hematopoietic necrosis virus in rainbow trout (Oncorhynchus mykiss). Vet Pathol 39:180-189

40. Chilmonczyk S, Winton JR (1994) Involvement of rainbow-trout leukocytes in the pathogenesis of infectious hematopoietic necrosis. Dis Aquat Organ 19:89-94

41. Harmache A, LeBerre M, Droineau S, Giovannini M, Bremont M (2006) Bioluminescence imaging of live infected salmonids reveals that the fin bases are the major portal of entry for Novirhabdovirus. J Virol 80:3655-3659

42. Dhar AK, Bowers RM, Licon KS, LaPatra SE (2008) Detection and quantification of infectious hematopoietic necrosis virus in rainbow trout (Oncorhynchus mykiss) by SYBR Green real-time reverse transcriptasepolymerase chain reaction. J Virol Methods 147:157-166

43. Foott JS, Free D, McDowell T, Arkush KD, Hedrick RP (2006) Infectious hematopoietic necrosis virus transmission and disease among juvenile Chinook salmon exposed in culture compared to environmentally relevant conditions. San Franc Estuary Watershed Sci 4:1-16

44. Armstrong R, Robinson J, Rymes C, Needham T (1993) Infectious hematopoietic necrosis in Atlantic salmon in British Columbia. Can Vet 34:312-313
45. St-Hilaire S, Ribble CS, Stephen C, Anderson E, Kurath G, Kent ML (2002) Epidemiological investigation of infectious hematopoietic necrosis virus in salt water net-pen reared Atlantic salmon in British Columbia, Canada. Aquaculture 212:49-67

46. Traxler GS, Roome JR, Lauda KA, LaPatra S (1997) Appearance of infectious hematopoietic necrosis virus (IHNV) and neutralizing antibodies in sockeye salmon Oncorhynchus nerka during their migration and maturation period. Dis Aquat Organ 28:31-38

47. Traxler GS, Roome JR, Kent ML (1993) Transmission of infectious hematopoietic necrosis virus in seawater. Dis Aquat Organ 16:111-114

48. LaPatra SE (1998) Factors affecting pathogenicity of infectious hematopoietic necrosis virus (IHNV) for salmonid fish. J Aquat Anim Health 10:121-131

49. Hetrick FM, Fryer JL, Knittel MD (1979) Effect of water temperature on the infection of rainbow-trout Salmo gairdneri Richardson with infectious hematopoietic necrosis virus. J Fish Dis 2:253-257

50. Amend DF (1970) Control of infectious hematopoietic necrosis virus disease by elevating water temperature. J Fish Res Bd Canada 27:265-270

51. Amend DF (1976) Prevention and control of viral diseases of salmonids. J Fish Res Bd Can 33:1059-1066

52. Amend DF, Nelson JR (1977) Variation in the susceptibility of sockeye salmon Oncorhynchus nerka to infectious haemopoietic necrosis virus. J Fish Biol 11:567-573

53. Kasai K, Yonezawa J, Ono A, Hasegawa A, Honma T, Fukuda H (1993) Brood and size dependent variation in susceptibility of rainbow trout, Oncorhynchus mykiss to artificial infection of infectious hematopoietic necrosis virus (IHNV). Fish Pathol 28:35-40

54. Wertheimer AC, Winton JR (1982) Differences in susceptibility among three stocks of chinook salmon, Oncorhynchus tshawytscha, to two isolates of infectious hematopoietic necrosis virus. U.S. Dept. of Commerce, National Oceanic and Atmospheric Administration, National Marine Fisheries Service

55. Quillet E, Dorson M, Le Guillou S, Benmansour A, Boudinot P (2007) Wide range of susceptibility to rhabdoviruses in homozygous clones of rainbow trout. Fish Shellfish Immunol 22:510-519

56. Overturf K, LaPatra S, Towner R, Campbell N, Narum S (2010) Relationships between growth and disease resistance in rainbow trout, Oncorhynchus mykiss (Walbaum). J Fish Dis 33:321-329

57. Overturf K, Casten MT, LaPatra SL, Rexroad C, Hardy RW (2003) Comparison of growth performance, immunological response and genetic diversity of five strains of rainbow trout (Oncorhynchus mykiss). Aquaculture 217:93-106

58. Parsons JE, Busch RA, Thorgaard GH, Scheerer PD (1986) Increased resistance of triploid rainbow trout $\times$ coho salmon hybrids to infectious hematopoietic necrosis virus. Aquaculture 57:337-343

59. Lapatra SE, Parsons JE, Jones GR, McRoberts WO (1993) Early life stage survival and susceptibility of brook trout, coho salmon, rainbow trout, and their reciprocal hybrids to infectious hematopoietic necrosis virus. $J$ Aquat Anim Health 5:270-274

60. Dorson M, Chevassus B, Torhy C (1991) Comparative susceptibility of three species of char and of rainbow trout $x$ char triploid hybrids to several pathogenic salmonid viruses. Dis Aquat Organ 11:217-224

61. Hedrick RP, LaPatra SE, Fryer JL, McDowell T, Wingfield WH (1987) Susceptibility of Coho (Oncorhynchus kisutch) and Chinook (Oncorhynchus tshawytscha) salmon hybrids to experimental infections with infectious hematopoietic necrosis virus (IHNV). Bull Eur Assoc Fish Pathol 7:97

62. LaPatra SE, Lauda KA, Jones GR, Shewmaker WD, Groff JM, Routledge D (1996) Susceptibility and humoral response of brown trout $\times$ lake trout hybrids to infectious hematopoietic necrosis virus: a model for examining disease resistance mechanisms. Aquaculture 146:179-188

63. Mclntyre JD, Amend DF (1978) Heritability of tolerance for infectious hematopoietic necrosis in sockeye salmon (Oncorhynchus nerka). Trans Am Fish Soc 107:305-308

64. Yamamoto S, Sanjyo I, Sato R, Kohara M, Tahara H (1991) Estimation of the heritability for resistance to infectious hematopoietic necrosis in rainbow trout. Nippon Suisan Gakkaishi 57:1519-1522

65. Palti Y, Parsons JE, Thorgaard GH (1999) Identification of candidate DNA markers associated with $\mathrm{IHN}$ virus resistance in backcrosses of rainbow (Oncorhynchus mykiss) and cutthroat trout (O. clarki). Aquaculture 173:81-94 
66. Palti Y, Nichols KM, Waller KI, Parsons JE, Thorgaard GH (2001) Association between DNA polymorphisms tightly linked to MHC class II genes and IHN virus resistance in backcrosses of rainbow and cutthroat trout. Aquaculture 194:283-289

67. Khoo SK, Ozaki A, Nakamura F, Arakawa T, Ishimoto S, Nickolov R, Sakamoto T, Akutsu T, Mochizuki M, Denda I, Okamoto N (2004) Identification of a novel chromosomal region associated with infectious hematopoietic necrosis $(\mathrm{IHN})$ resistance in rainbow trout Oncorhynchus mykiss. Fish Pathol 39:95-101

68. Miller KM, Winton JR, Schulze AD, Purcell MK, Ming TJ (2004) Major histocompatibility complex loci are associated with susceptibility of Atlantic salmon to infectious hematopoietic necrosis virus. Environ Biol Fishes 69:307-316

69. Barroso RM, Wheeler PA, LaPatra SE, Drew RE, Thorgaard GH (2008) QTL for IHNV resistance and growth identified in a rainbow (Oncorhynchus mykiss) $\times$ Yellowstone cutthroat (Oncorhynchus clarki bouvieri) trout cross. Aquaculture 277:156-163

70. Barroso R, Wheeler PA, Lapatra S, Drew RE, Thorgaard GH (2007) QTL for IHNV resistance and growth identified in a rainbow $(x)$ cutthroat trout cross. Aquaculture 272:243-244

71. Purcell MK, LaPatra SE, Woodson JC, Kurath G, Winton JR (2010) Early viral replication and induced or constitutive immunity in rainbow trout families with differential resistance to Infectious hematopoietic necrosis virus (IHNV). Fish Shellfish Immunol 28:98-105

72. Trobridge GD, LaPatra SE, Kim CH, Leong JC (2000) Mx mRNA expression and RFLP analysis of rainbow trout Oncorhynchus mykiss genetic crosses selected for susceptibility or resistance to IHNV. Dis Aquat Organ 40:1-7

73. Campbell NR, LaPatra SE, Overturf K, Towner R, Narum SR (2014) Association mapping of disease resistance traits in rainbow trout using restriction site associated DNA sequencing. G3:2473-2481

74. Burke J, Grischkowsky R (1984) An epizootic caused by infectious haematopoietic necrosis virus in an enhanced population of sockeye salmon, Oncorhynchus nerka (Walbaum), smolts at Hidden Creek, Alaska. J Fish Dis 7:421-429

75. Traxler GS (1986) An epizootic of infectious haematopoietic necrosis in 2-year-old kokanee, Oncorhynchus nerka (Walbaum) at Lake Cowichan, British Columbia. J Fish Dis 9:545-549

76. Arkush KD, Mendonca HL, McBride AM, Hedrick RP (2004) Susceptibility of captive adult winter-run Chinook salmon Oncorhynchus tshawytscha to waterborne exposures with infectious hematopoietic necrosis virus (IHNV). Dis Aquat Organ 59:211-216

77. LaPatra SE, Groberg WJ, Rohovec JS, Fryer JL (1990) Size-related susceptibility of salmonids to 2 strains of infectious hematopoietic necrosis virus. Trans Am Fish Soc 119:25-30

78. Ogut H, Reno PW (2004) Effects of fish density on spread of infectious hematopoietic necrosis virus (IHNV) in rainbow trout, Oncorhynchus mykiss. Isr J Aquacult Bamid 56:218-225

79. Mulcahy D, Jenes CK, Pascho R (1984) Appearance and quantification of infectious hematopoietic necrosis virus in female sockeye salmon (Oncorhynchus nerka) during their spawning migration. Arch Virol 80:171-181

80. Follett JE, Burton TO (1995) Epizootics of infectious hematopoietic necrosis virus in an enhanced population of sockeye salmon Oncorhynchus nerka smolts at Chenik Lake, Alaska. Alaska Fish Res Bull 2:137-142

81. Follett JE, Thomas JB, Hauck AK (1987) Infectious hematopoietic necrosis virus in moribund and dead juvenile chum, Oncorhynchus keta (Walbaum), and chinook, Oncorhynchus tshawytscha (Walbaum), salmon and spawning adult chum salmon at an Alaskan hatchery. J Fish Dis 10:309-313

82. Mulcahy D, Pascho RJ, Jenes CK (1983) Detection of infectious haematopoietic necrosis virus in river water and demonstration of waterborne transmission. J Fish Dis 6:321-330

83. Hetrick FM, Knittel MD, Fryer JL (1979) Increased susceptibility of rainbow trout to infectious hematopoietic necrosis virus after exposure to copper. Appl Environ Microbiol 37:198-201

84. Spitsbergen JM, Schat KA, Kleeman JM, Peterson RE (1988) Effects of 2,3,7,8-tetrachlorodibenzo-p-dioxin or Aroclor 1254 on the resistance of rainbow trout, Salmo gairdneri Richardson, to infectious haematopoietic necrosis virus. J Fish Dis 11:73-83
85. Eder KJ, Clifford MA, Hedrick RP, Kohler HR, Werner I (2008) Expression of immune-regulatory genes in juvenile Chinook salmon following exposure to pesticides and infectious hematopoietic necrosis virus (IHNV). Fish Shellfish Immunol 25:508-516

86. Eder KJ, Koehler H-R, Werner I (2007) Pesticide and pathogen: heat shock protein expression and acetylcholinesterase inhibition in juvenile Chinook salmon in response to multiple stressors. Environ Toxicol Chem 26:1233-1242

87. Foreman MGG, Guo M, Garver KA, Stucchi D, Chandler P, Wan D, Morrison J, Tuele D (2015) Modelling infectious hematopoietic necrosis virus dispersion from marine salmon farms in the Discovery Islands, British Columbia Canada. PLoS One 10:e0130951

88. Bootland LM, Lorz HV, Rohovec JS, Leong JC (1994) Experimental infection of brook trout with infectious hematopoietic necrosis virus types 1 and 2. J Aquat Anim Health 6:144-148

89. Yamamoto T, Arakawa CK, Batts WN, Winton JR (1989) Comparison of infectious hematopoietic necrosis in natural and experimental infections of spawning salmonids by infectivity and immunohistochemistry. In: Ahne W, Kurstak E (eds) Viruses of lower vertebrates. Springer, Berlin

90. LaPatra SE, Fryer JL, Rohovec JS (1993) Virulence comparison of different electropherotypes of infectious hematopoietic necrosis virus. Dis Aquat Organ 16:115-120

91. Leong JC, Hsu YL, Engelking HM, Mulcahy D (1981) Strains of infectious hematopoietic necrosis (IHN) virus may be identified by structural protein differences. Dev Biol Stand 49:43-55

92. Hsu YL, Engelking HM, Leong JC (1986) Occurrence of different types of infectious hematopoietic necrosis virus in fish. Appl Environ Microbiol 52:1353-1361

93. LaPatra SE, Groff JM, Fryer JL, Hedrick RP (1990) Comparative pathogenesis of three strains of infectious hematopoietic necrosis virus in rainbow trout Oncorhynchus mykiss. Dis Aquat Organ 8:105-112

94. LaPatra S, Fryer JL, Wingfield WH, Hedrick RP (1989) Infectious hematopoietic necrosis virus (ihnv) in coho salmon. J Aquat Anim Health 1:277-280

95. Chen MF, Aikens CM, Fryer JL, Rohovec JS (1990) Virulence of four isolates of infectious hematopoietic necrosis virus in salmonid fishes and comparative replication in salmonid fish cell lines. Calif Fish Game 76:137-145

96. Garver KA, Batts WN, Kurath G (2006) Virulence comparisons of infectious hematopoietic necrosis virus $U$ and $M$ genogroups in sockeye salmon and rainbow trout. J Aquat Anim Health 18:232-243

97. Troyer RM, Kurath G (2003) Molecular epidemiology of infectious hematopoietic necrosis virus reveals complex virus traffic and evolution within southern Idaho aquaculture. Dis Aquat Organ 55:175-185

98. Kell AM, Wargo AR, Kurath G (2014) Viral fitness does not correlate with three genotype displacement events involving infectious hematopoietic necrosis virus. Virology 464-465:146-155

99. Mulcahy D, Wood J (1986) A natural epizootic of infectious hematopoietic necrosis in imported Atlantic salmon, Salmo salar L, reared in the enzootic region. J Fish Dis 9:173-175

100. Yamazaki T, Motonishi A (1992) Control of infectious hematopoietic necrosis and infectious pancreatic necrosis in salmonid fish in Japan, In: Proceedings OJI International Symposium salmonid diseases. Hokkaido University Press, Sapporo, p 103-110

101. Engelking HM, Kaufman J (1994) Brown trout (Salmo trutta) loss to infectious hematopoietic necrosis virus (IHNV). Fish Health Newslett AFS/FHS 22:20-22

102. Knusel R, Bergmann SM, Einer-Jensen K, Casey J, Segner H, Wahli T (2007) Virus isolation vs RT-PCR: which method is more successful in detecting VHSV and IHNV in fish tissue sampled under field conditions? J Fish Dis 30:559-568

103. Müller A, Sutherland BJG, Koop BF, Johnson SC, Garver KA (2015) Infectious hematopoietic necrosis virus (IHNV) persistence in sockeye salmon: Influence on brain transcriptome and subsequent response to the viral mimic poly(l:C). BMC Genomics 16:634

104. Kim CH, Dummer DM, Chiou PP, Leong JAC (1999) Truncated particles produced in fish surviving infectious hematopoietic necrosis virus infection: mediators of persistence? J Virol 73:843-849

105. St-Hilaire S, Ribble CS, LaPatra SE, Chartrand S, Kent ML (2001) Infectious hematopoietic necrosis virus antibody profiles in naturally and experimentally infected Atlantic salmon Salmo salar. Dis Aquat Organ 46:7-14 
106. Drolet BS, Chiou PP, Heidel J, Leong JA (1995) Detection of truncated virus particles in a persistent RNA virus infection in vivo. J Virol 69:2140-2147

107. St-Hilaire S, Ribble C, Traxler G, Davies T, Kent ML (2001) Evidence for a carrier state of infectious hematopoietic necrosis virus in chinook salmon Oncorhynchus tshawytscha. Dis Aquat Organ 46:173-179

108. Palmer AD, Emmenegger EJ (2014) Susceptibility of Koi and Yellow Perch to infectious hematopoietic necrosis virus by experimental exposure. J Aquat Anim Health 26:78-83

109. Ogut H, Reno PW (2004) Early kinetics of infectious hematopoietic necrosis virus (IHNV) infection in rainbow trout. J Aquat Anim Health $16: 152-160$

110. Meyers TR, Korn D, Burton TM, Glass K, Follett JE, Thomas JB, Sullivan J, Starkey N, Short S, Lipson K (2003) Infectious hematopoietic necrosis virus (IHNV) in Alaskan sockeye salmon culture from 1973 to 2000: annual virus prevalences and titers in broodstocks compared with juvenile losses. J Aquat Anim Health 15:21-30

111. Grischkowsky RS, Amend DF (1976) Infectious hematopoietic necrosis virus: prevalence in certain Alaskan sockeye salmon, Oncorhynchus nerka. J Fish Res Bd Canada 33:186-188

112. Knuesel $R$, Segner $H$, Wahli $T$ (2003) A survey of viral diseases in farmed and feral salmonids in Switzerland. J Fish Dis 26:167-182

113. Ahne W, Joergensen PEV (1993) Prevalence of neutralising antibodies to IHNV and VHSV in free-living and cultured rainbow trout in Germany. Bull Eur Assoc Fish Pathol 13:7-9

114. Saksida SM (2006) Infectious haematopoietic necrosis epidemic (2001 to 2003) in farmed Atlantic salmon Salmo salar in British Columbia. Dis Aquat Organ 72:213-223

115. Anonymus (2011) Survey and diagnosis; 15th Annual Meeting of the National Reference Laboratories for Fish Diseases. Aarhus, Denmark. http://www.eurl-fish.eu/Activities/EURL_reports. Accessed 28 Apr 2016

116. Olesen NJ, Vendramin N (2015) Survey and diagnosis of fish diseases in 2014. 19th Annual Workshop of the National Reference Laboratories for Fish Diseases. Copenhagen, Denmark. http://www.eurl-fish.eu/Activities/survey_and_diagnosis. Accessed 3 Mar 2016

117. Penaranda MMD, Wargo AR, Kurath $G$ (2011) In vivo fitness correlates with host-specific virulence of Infectious hematopoietic necrosis virus (IHNV) in sockeye salmon and rainbow trout. Virology 417:312-319

118. LaPatra SE, Rohvec JS, Fryer JL (1989) Detection of infectious hematopoietic necrosis virus in fish mucus. Fish Pathol 24:197-202

119. Mulcahy D, Pascho RJ, Batts WN (1987) Testing of spawning male sockeye salmon (Oncorhynchus nerka) and steelhead trout (Salmo gairdneri) for infectious hematopoietic necrosis virus. Can J Fish Aquat Sci 44:1075-1078

120. Mulcahy D, Pascho RJ, Jenes CK (1983) Titer distribution patterns of infectious hematopoietic necrosis virus in ovarian fluids of hatchery and feral salmon populations. J Fish Dis 6:183-188

121. Amend DF (1975) Detection and transmission of infectious hematopoietic necrosis virus in rainbow trout. J Wildl Dis 11:471-478

122. Nishimura T, Ishida Y, Yamamoto S, Fukuda H, Okamoto N, Sano T (1988) Infectious hematopoietic necrosis - virus titer in the fish bodies, rearing water and feces of artificially infected rainbow-trout fry. Fish Pathol 23:13-17

123. Watanabe RA, Fryer JL, Rohovec JS (1988) Molecular filtration for recovery of waterborne viruses of fish. Appl Environ Microbiol 54:1606-1609

124. Yoshimizu M, Sami M, Kohara M, Yamazaki T, Kimura T (1991) Detection of IHNV in hatchery water by molecular filtration method and effectiveness of U.V. irradiation on IHNV infectivity. Nippon Suisan Gakkaishi 57:555-560

125. Zhang Y, Congleton JL (1994) Detection of infectious hematopoietic necrosis $(\mathrm{IHN})$ virus in rearing units for steelhead before and during $\mathrm{IHN}$ epizootics. J Aquat Anim Health 6:281-287

126. Mulcahy D, Pascho RJ (1984) Adsorption to fish sperm of vertically transmitted fish viruses. Science 225:333-335

127. Mulcahy D, Pascho RJ (1985) Vertical transmission of infectious hematopoietic necrosis virus in sockeye salmon, Oncorhynchus nerka (Walbaum) -isolation of virus from dead eggs and fry. J Fish Dis 8:393-396

128. Yoshimizu M, Sami M, Kimura T (1989) Survivability of infectious hematopoietic necrosis virus in fertilized eggs of masu and chum salmon. J Aquat Anim Health 1:13-20
129. Roberts SD (1993) IHN at Lyons Ferry Hatchery: a case study of vertical transmission. Fish Health Sect Am Fish Soc Newslett 21:13-14

130. Goldes SA, Mead SL (1995) Efficacy of iodophor disinfection against egg surface-associated infectious hematopoietic necrosis virus. Prog Fish-Cult 57:26-29

131. LaPatra SE, Lauda KA, Jones GR, Walker SC, Shewmaker BS, Morton AW (1995) Characterization of IHNV isolates associated with neurotropism. Vet Res 26:433-437

132. Barlic-Maganja D, Strancar M, Hostnik P, Jencic V, Grom J (2002) Comparison of the efficiency and sensitivity of virus isolation and molecular methods for routine diagnosis of infectious haematopoietic necrosis virus and infectious pancreatic necrosis virus. J Fish Dis 25:73-80

133. Bergmann SM, Ariel E, Skall HF, Fichtner D, Schlotfeldt HJ, Olesen NJ (2002) Comparison of diagnostical methods for detection of an infection with different isolates of infectious haematopoietic necrosis virus (IHNV). Berl Munch Tierarztl Wochenschr 115:385-389

134. Hostnik P, Barlic-Maganja D, Strancar M, Jencic V, Toplak I, Grom J (2002) Influence of storage temperature on infectious hematopoietic necrosis virus detection by cell culture isolation and RT-PCR methods. Dis Aquat Organ 52:179-184

135. McClure C, Saksida S, Karreman G, Constantine J, Robinson J, Traxler G, Hammell L (2008) Evaluation of a reverse transcriptase polymerase chain reaction test and virus isolation on field samples collected for the diagnosis of infectious hematopoietic necrosis virus in cultured Atlantic salmon in British Columbia. J Aquat Anim Health 20:12-18

136. Purcell MK, Thompson RL, Garver KA, Hawley LM, Batts WN, Sprague L, Sampson C, Winton JR (2013) Universal reverse-transcriptase real-time PCR for infectious hematopoietic necrosis virus (IHNV). Dis Aquat Organ 106:103-115

137. Emmenegger EJ, Meyers TR, Burton TO, Kurath G (2000) Genetic diversity and epidemiology of infectious hematopoietic necrosis virus in Alaska. Dis Aquat Organ 40:163-176

138. LaPatra SE, Batts WN, Overturf K, Jones GR, Shewmaker WD, Winton JR (2001) Negligible risk associated with the movement of processed rainbow trout, Oncorhynchus mykiss (Walbaum), from an infectious haematopoietic necrosis virus (IHNV) endemic area. J Fish Dis 24:399-408

139. Evelyn TPT (2001) The effects of chilling, freezing and cold-smoking on the infectious titre of certain microbial fish pathogens that may occasionally be present in marketed salmonid flesh. In: Rodgers CJ (ed) Risk Analysis in Aquatic Animal Health. OlE, Paris, pp 215-229

140. Pietsch JP, Amend DF, Miller CM (1977) Survival of infectious hematopoietic necrosis virus held under various environmental conditions. J Fish Res Bd Canada 34:1360-1364

141. Gosting LH, Gould RW (1981) Thermal inactivation of infectious hematopoietic necrosis and infectious pancreatic necrosis viruses. Appl Environ Microbiol 41:1081-1082

142. Oidtmann B, Johnston C, Klotins K, Mylrea G, Van PT, Cabot S, Martin PR, Ababouch L, Berthe F (2013) Assessment of the safety of aquatic animal commodities for international trade: the OIE aquatic animal health code. Transbound Emerg Dis 60:27-38

143. EFSA (2007) Scientific Opinion of the Panel on Animal Health and Welfare on a request from the European Commission on possible vector species and live stages of susceptible species not transmitting disease as regards certain fish diseases. EFSA J 584:1-163

144. Mulcahy D, Klaybor D, Batts WN (1990) Isolation of infectious hematopoietic necrosis virus from a leech (Piscicola salmositica) and a copepod (Salmincola sp.) ectoparasites of sockeye salmon Oncorhynchus nerka. Dis Aquat Organ 8:29-34

145. Shors ST, Winston V (1989) Detection of infectious hematopoietic necrosis virus in an invertebrate (Callibaetis sp.). Am J Vet Res 50:1307-1309

146. Jakob E, Barker DE, Garver KA (2011) Vector potential of the salmon louse Lepeophtheirus salmonis in the transmission of infectious haematopoietic necrosis virus (IHNV). Dis Aquat Organ 97:155-165

147. Ritchie $G$ (1997) The host transfer ability of Lepeophtheirus salmonis (Copepoda: Caligidae) from farmed Atlantic salmon, Salmo salar L. J Fish Dis 20:153-157

148. Nardy E, Wortberg F, Kuhn R, Enzmann JP, Kramer M (2008) IHNAusbrüche im Schwarzwald im Jahr 2006-Erkenntnisse und Schlussfolgerungen, XII. German, Austrian and Swiss EAFP-Conference, Jena 
149. Mulcahy D, Burke J, Pascho R, Jenes CK (1982) Pathogenesis of infectious hematopoietic necrosis virus in adult sockeye salmon (Oncorhynchus nerka). Can J Fish Aquat Sci 39:1 144-1149
150. Burke J, Mulcahy D (1983) Retention of infectious hematopoietic necrosis virus infectivity in fish tissue-homogenates and fluids stored at 3 temperatures. J Fish Dis 6:543-547

\section{Submit your next manuscript to BioMed Central} and we will help you at every step:

- We accept pre-submission inquiries

- Our selector tool helps you to find the most relevant journal

- We provide round the clock customer support

- Convenient online submission

- Thorough peer review

- Inclusion in PubMed and all major indexing services

- Maximum visibility for your research

Submit your manuscript at www.biomedcentral com/submit
() Biomed Central 